\title{
'Curse, bless, me now': Dylan Thomas and Saunders Lewis
}

\author{
Chatterton Lecture on Poetry \\ read 24 October 2014 \\ TUDUR HALLAM
}

Abstract: Dylan Thomas, the Swansea-born writer of English, and Saunders Lewis, the Wallasey-born writer of Welsh, are usually set in differing discursive camps. Memorable quotations - 'I cannot read Welsh', to quote Dylan; 'He belongs to the English', to quote Saunders - continually drive them apart. Focusing on 1938, the year in which Dylan Thomas published his elegy to his aunt, 'After the Funeral', and in which Saunders Lewis delivered his lecture 'Is There an Anglo-Welsh Literature?', this paper considers how the former's life and work might be read differently in conjunction with the latter's. The authors' differences and similarities are discussed, and the work of William Williams Pantycelyn, author of 'Guide me, O Thou Great Jehovah' is read in the light of Saunders Lewis's classic study of his romanticism so as to suggest not only a tangible link between the two poetic non-conformists, but also a means of appreciating Dylan Thomas's own aesthetic development as a poet.

Keywords: Dylan Thomas, Saunders Lewis, poetics, romanticism, post-colonialism, Welsh literature, Swansea.

Though 'knowledge of the Welsh background is now a sine qua non of serious Dylan Thomas criticism' (Ackerman 1998: 7), there are many of us, who live in that Welsh background, and who love poetry, who are quite unfamiliar with the work of Dylan Thomas. He is simply not part of our world. For me, this partly is due to the fact that I have predominantly lived and worked all my life, not in Carmarthenshire and Swansea, but in Sir Gaerfyrddin and Abertawe. The literary tradition from which I write is completely Welsh, and by Welsh, as Dylan Thomas himself once remarked in a radio broadcast, I mean 'Welsh poetry ... written in the Welsh language' (1991b edn: 31). But also, even when I studied English literature at school until the age of eighteen, Dylan 
Thomas was never a feature of the literary curriculum. Why? John Goodby is surely right to suggest that Dylan Thomas's hybridity excludes him from several discursive camps (Goodby 2013: 452). In my own experience, however, it seemed that he belonged to a different language, a different world.

Today, even in this age of interdisciplinary and bicultural flux, Dylan Thomas (1914-1953) remains very much the preserve of the English department. Departments of Welsh - those of us concerned with studying the Welsh language, its history, culture and planning - have not concerned ourselves very much either with Dylan Thomas's work or his story. So it is, at least in my experience at Swansea University, where my colleagues, Professors John Goodby, M. Wynn Thomas and Daniel G. Williams were called upon extensively in the poet's centenary year to celebrate the life and work of 'Swansea's most famous son'; witness their contributions to Hannah Ellis's Dylan Thomas: A Centenary Celebration (2014). There are others too in the English department at Swansea, Dr Steve Vine and the playwright Professor David Britton, for example, who have further increased academic and public enjoyment of Dylan Thomas's life and work.

In inviting a Professor of Welsh (and a poet who writes exclusively in Welsh) to say something about Dylan Thomas's poetry, the British Academy is inevitably, to my mind at least, conducting a curious kind of socio-literary experiment - not too dissimilar to those once-popular reality-TV programmes, 'Wife Swap' or 'Living with the Enemy', in which two individuals left the comfort of their familial and familiar environment in order to experience at first hand another way of life. More often than not, such 'swaps', or confrontations with 'the other', drew upon the opposed parties' common bonds of humanity and marked out not only the differences, but also the similarities. The swap, on this occasion, is between Dylan Thomas and myselfremembering that, as suggested, I had, until recently, read only a small selection of Thomas's poems, and that some twenty years ago. ${ }^{1}$ The Academy's kind invitation is, of course, wholly in keeping with the bicultural aims stated by M. Wynn Thomas (FBA) in his study Corresponding Cultures: The Two Literatures of Wales, namely to read 'across the language divide' in Wales in the hope that previously held beliefs might be 'significantly altered' (1999: 65).

\footnotetext{
${ }^{1}$ This reading was encouraged by one of Dylan Thomas's critics, Professor Emeritus R. M. (Bobi) Jones (FBA), who suggested that I focused on six or seven of Dylan Thomas's poems whilst making my way through the English canon, and, more importantly, everything else I could get my hands on, either in the original languages or in translation (into Welsh or English).
} 


\section{A COMMON, COMPLEX, CULTURAL CONDITION}

While I have, for the purposes of this paper, immersed myself in Dylan Thomas's poems and prose and attended centenary talks, exhibitions and conferences, he too, in his turn, has begun to inhabit my working days and occupy my places of study. Consequently, he has by degrees been admitted to the company of those poets, critics and experiences who have formed my poetics and influenced my way of looking at this world. I particularly wanted him to meet my great literary grand-father (anastrophe intended), Saunders Lewis (1893-1985), best known perhaps for co-founding Plaid Cymru, the National Party of Wales, in 1925, and for inspiring the young activists of Cymdeithas yr Iaith Gymraeg [the Welsh Language Society] in 1962. The first of these two political acts occurred a few years after Saunders Lewis had been appointed as lecturer in Welsh literature at University College, Swansea, in 1922, where he proceeded both to teach and to produce his earliest creative works until his dismissal for a political act of arson at Penyberth, Gwynedd, in 1936.

During Dylan Thomas's formative years as a boy, he and Saunders Lewis lived, at one time, within a crow's mile of each other in Uplands, Swansea. They breathed the same air and cursed the same rain (Lewis 1993 edn: 396, 522; Thomas 1985 edn: 29, 191), and one might be forgiven for thinking from reading their letters that 'Swansea was always raining' (Sinclair 1999: 33). Both men, however, were also dazzled by the Swansea-Bay light and the coastal scenery beyond Mumbles towards the Gower (Lewis, 1993 edn: 274-5, 354, 499, 529; Thomas 1985 edn: 85, 114, 145). In age, they were separated by no more than a generation, and there is much that is similar in their descriptions of the 'ugly, lovely town' in which they lived (Thomas 1991a edn: 3; Chapman 2006: 39). Both found Swansea to be 'horribly heavy and relaxing' (Lewis 1993 edn: 263, 331, 354, 511). Like many a Swansea suburbanite, they both liked and disliked the place - avenue trees with no forests, chapels without revivals, folk with no living literary tradition of their own - 'suburban scum', as Thomas so kindly put it (Thomas 1985 edn: 110). But also there was always, as if by God's grace, the attraction of the sea, its light and its movement, not to mention the countryside walk to Gower and the splendour of Worm's Head, or perhaps even 'motoring to Carmarthen', the county in which so many of Dylan Thomas's best poems and stories are set (Lewis 1993 edn: 354, 395; Thomas 1985 edn: 62, 372). For both men, Gower and Carmarthenshire were Swansea's 'compensations' (Lewis 1993 edn: 499; Thomas 1985 edn: 21, 174), and in Thomas's case, one might add the name of Cwmdonkin Park, 'a world within the world of the sea-town' (1991a edn: 3).

As a poet, Thomas 'loves and praises a very small geographical region-little patches in South Wales, in West Glamorganshire and Carmarthenshire' (Hardy 2000: 4). But I would concur with John Goodby—although not so loudly as to scare 
away the tourists, of course - that he is more often a poet of 'locatedness' than of locality (Goodby 2013: 383), a poet of artistic feeling rather than of realistic description. So, although a keen sense of claustrophobia at times permeates the letters both of Dylan Thomas and of Saunders Lewis to their loved ones, not to mention the odd outburst of disgust towards family members and surroundings, they also exude a sense of contentment, and even occasionally a sense of joy and wonder, which, especially in Thomas's case, grows 'strong and sentimental' (Lewis 1993 edn: 263, 334, 502; Thomas 1985 edn: 364, 195-9). This nexus of contradictory attitudes is summed up nicely in the memorable line of a letter from Dylan Thomas to Pamela Hansford Johnson: 'Swansea is a dingy hell, and my mother is a vulgar humbug; but I'm not so bad, and Gower is as beautiful as anywhere' (1985 edn: 65).

Once, when writing to impress the metropolitan Johnson, whose more precocious and sophisticated literary gifts seemed to bring out the 'very melodramatic' in the callow provincial Welshman (1985 edn: 30), the young Thomas described how he wanted 'to get out of it all, out of narrowness and dirtiness, out of the eternal ugliness of the Welsh people' (1985 edn: 30). A comparison might be made here, not only with Owen Morgan-Vaughan's infamous rant against the Welsh in Thomas's filmscript, The Three Weird Sisters (Thomas 1995b edn: 299)—which includes incidentally a line of cynghanedd: 'How vile was my valley!'² - but also with Saunders Lewis's surrogate character, Dewi, in his play Cymru Fydd first performed in1967 (2000a edn: 565-634) [Future Wales], for he too attacks the people of his own country with real venom and spite, sharing something of young Thomas's 'natural hatred of Wales' (1985 edn: 100). Mocking his girlfriend, Bet, for cherishing 'God, religion, church or chapel, Wales, the Welsh language' (2000a edn: 602), Dewi proclaims that he is the embodiment of future Wales, before proceeding first to deceive Bet and then to kill himself.

Thomas and Lewis, then, shared the world of 'Swansea', and contributed jointly to the town's cultural and intellectual 'movement' in the early 1930s (Kershner 1976: 173). It would, however, be more correct to say that they were both inhabitants not of 'Swansea' but of 'Swansea-Abertawe' (or 'Abertawe-Swansea'), a cultural hybrid that served a bilingual and bicultural hinterland. They thus inhabited what Homi Bhabha has influentially termed the "third space" which enables other positions to emerge' (1994: 211).

\footnotetext{
${ }^{2}$ I've been driving for hours and hours, slag heaps and pit heads and vile black hills. Huh! How vile was my valley! I'm sick of all this Celtic clap trap about Wales. My Wales! (mockingly) Land of my Fathers! As far as I'm concerned, my fathers can keep it. You can tell he's a Welshman by the lilt in his voice. Huh, little black back-biting hypocrites, all gab and whine! Black beetles with tenor voices and a sense of sin like a crippled hump. Cwmglas! Full of senile morons and vicious dwarfs, old poles of women clacking at you like blowsy hens, self-righteous little humbugs with the hwyl, old men with beards in their noses cackling at you, blue gums and clackers. Oh the mystical Welsh—huh! About as mystical as slugs!
} 
What, then, of their respective early backgrounds? Born and raised in Wallasey, Lewis was in effect a Welsh immigrant in England, whose chapel and familial language was Welsh. Dylan Thomas, contrastingly, was an English-speaking child in Wales, whose parents, extended family and a number of close personal friends spoke Welsh. Accordingly, in the latter's prose, the sea is a 'bilingual sea', 'the two-tongued sea', and it is described as 'crackling' (1983 edn: 293, 296, 298). For both men, this 'crackle' of bilingualism is a source of energy and tension. While it sent them in different and new directions, it also bound them together in a common, if complex, cultural condition. Accordingly, the similarities between these two 'exotic' and 'socially misplaced' men are striking (Thomas, M. W. 2000: 125). Both rebelled against the non-conformist chapel, and both, on separate literary occasions in Scotland, vigorously attacked non-conformist Wales (Thomas 1953; Lewis 1929), before realising, of course, in time, that a Calvinistic upbringing is not something one can so easily disregard. Both, too, were too hot for the University of Wales to handle (Thomas 1985 edn: 735).

Though Saunders Lewis's mother tongue was Welsh, and though he was influenced by his father's high regard for Welsh letters, he was (not surprisingly, given his upbringing in Wallasey) a typical product of the English education system. And so was Dylan Thomas, whose education at the socially prestigious Swansea Grammar School was specifically designed to ensure he would be 'closer to the traditions of England than of Wales' (Tindall 1996 edn: 11). The young Lewis even set out to be an English poet, rather than a Welsh 'bardd' (1993 edn: 155). Although he recognised that such early attempts as his poem 'The End of All Things', written in 1915, were no better than the compositions of 'a writer of the merest verse' (1993 edn: 155), English continued to be his preferred language for several years. Consequently, his very first play, The Eve of Saint John in 1920 (1996 edn: 15-31), was written in a curiously devised 'AngloWelsh' dialect, modelled on Synge's synthetic Anglo-Irish.

'Too Welsh for the English, too English for the Welsh'-Dylan Thomas's famous remark on his own identity as that of 'a border case' (1953) was also true of Saunders Lewis, though, subsequently, it might be said that he was also too Welsh, too Cymreig, for both the English and Welsh establishments. Unlike the traditional Welsh poet Alun Cilie (see below), Lewis was no more of a bardd gwlad - a classical Welsh praise poet, in service to his or her community - than was Dylan Thomas. Both writers gazed upon their worlds objectively, viewing them as outsiders, or, at best, as returning natives; and to some extent, though both were modernist poets, one feels that they both adopted a rather romantic view of Wales which took little note of its industrial valleys.

Like Dylan Thomas's wife, Caitlin Macnamara, Lewis's wife, Margaret Gilcriest, was of Irish descent and not Welsh-speaking (Lewis 1993 edn: 507). Leaving Wales, 
escaping non-conformist claustrophobia with their loved ones, was something both men had cause to contemplate. For in 1924, to avoid the scandal of his marriageMargaret, though of a Protestant family, was Catholic, and his father a Calvinistic minister-Saunders Lewis considered leaving the Welsh department in Swansea for 'the vacant English chair at Exeter', and also applied for other posts in Manchester and Dublin (1993 edn: 533, 537, 539). A year later, however, with his family's acceptance of Margaret assured, he co-founded the National Party of Wales, and committed himself to making Welsh not only the language of poets and preachers but also of Welsh government officials and radio stations. That course of action, as already mentioned, would eventually lead to his sacking and imprisonment. With no prospect of an academic post in sight, there was talk amongst his friends of securing 'an American lecturing job or tour' (Lewis 1993 edn: 609, 622) - a venture, of course, which later transformed Dylan Thomas into an international phenomenon (Brinnin 1957).

One can also mention the literary influences which both Swansea suburbanites had in common: Shakespeare, the English Romantics, T. S. Eliot, Yeats, surrealism, Freud. Their paths, however, continually diverge towards different destinations, belonging as they do to two different languages and cultures. Both are (mis)represented by their supporters and detractors, of course, and they often exist as selectively quoted clowns or demons.

In the mid-1930s, Dylan Thomas left Swansea for London; Saunders Lewis, for Wormwood Scrubs. Both men, however, returned to live in West Wales, though if the latter is mentioned at all in the context of the former, it is mostly in order to highlight those qualities which Dylan Thomas supposedly lacked: Welsh conservatism and essentialism (Goodby 2013: 282). For the most part, however, Saunders Lewis remains unknown even to the most learned critic of English literature, and, if mentioned, is seen as a spent force in the political domain. The irony of course, at least for me, is that Dylan Thomas, who was seemingly and unavoidably everywhere during his centenary year - celebrated at seminars, festivals and parties, cultivated anew by a host of productions and programmes, spawning surreal events such as amateur dancing on the streets of Caerfyrddin-Carmarthen, not to mention BBC-commissioned dramas - is the sponsored, pampered child of those very national agencies for the creation of which Saunders Lewis fought a lonely battle throughout his life, namely the Welsh government and, as Dylan Thomas once referred to it, 'the Welsh BBC' (Thomas 1985 edn: 707, 793, 876, 894). When considering the contemporary cases of Lewis and Thomas, therefore, one is dealing not simply with a case of parallelism, but of politics and power. We are witnessing the way in which Saunders Lewis, the now forgotten poet-politician, prepared the way for the linguistically acceptable 'Welsh 
poet', Dylan Thomas, to be championed by his country's First Minister, in the company of Ireland's Head of State (Audley 2014). And Thomas, once routinely treated as an English poet who happened to have come from Wales, is now celebrated as if he were a long-established national poet of Wales whose work just happens to be in English. To those, however, who argue that Wales should follow Ireland's example, and use 'Welsh' as 'Irish' is used to denote all writing by Irish-born, or Irish-located writers, in whatever language (Goodby \& Wigginton 2001: 8), I would remind them that, a few months preceding the President's visit to Wales, Ireland's language commissioner, Seán Ó Cuirreáin, resigned 'over government failures to promote the Irish language' (Ryan 2014), and that Ireland, therefore, is not necessarily the best model for those of us who believe that Welsh literature, and Welsh writing in English for that matter, is best served by the continued existence of thriving Welsh-speaking communities.

Though the mythical Dylan Thomas will forever be seen and celebrated as the wild child of Wales, it is simply a fallacy to believe that the conservative, Catholic Lewis was in any way less radical than the bohemian bard. In 1930, for example, a few years before Dylan Thomas took the literary scene in London by storm, Saunders Lewis's novel, Monica (Lewis 1930a), caused uproar in Wales, touching as it did on prostitution and sexual disease. That same year, his radio lecture was censored by the BBCfor the obscene suggestion that the life and energy of the Welsh literary revival should break out into the political domain (Lewis 1930b). Nowadays, not only is the novel in Welsh flourishing, but devolving more legislative powers to Wales is firmly on the political agenda of all mainstream political parties. In Lewis, even the Marxist historian, Gwyn Alf Williams, though 'at the opposite pole of the political spectrum', could still recognise 'a genius, a marvellous writer, a man utterly committed to Wales who has, virtually by himself, reshaped Welsh history' (1984).

Though uncelebrated and little known outside Wales today, Saunders Lewis did actually make it into one of Dylan Thomas's short stories, 'Where Tawe Flows'. There the likeable nationalist, Mr Roberts, 'a cheerful, disreputable man of middle age', hails his name in a fascist jest-'Heil, Saunders Lewis!' - as he and his friends storm their friend's front door: 'We're Ogpu men, let us in.' 'We're looking for seditious literature' - a reference, perhaps, to Monica, if not also to Lewis's political writings, for which Thomas had very little time or sympathy, though his friend Keidrych Rhys (Mr Roberts, perhaps) was nevertheless 'an ardent nationalist' (Thomas 1983 edn: 181; 1985 edn: 301; Ferris 1999: 163). Read in light of how, following Lewis's dismissal from his college post in 1937, 'ordinary Swansea people were so "possessive" of him and claiming him as their own' (Jones G. in Lewis 1993 edn: 617) —who said he was too Welsh for the Welsh? - the reference in 'Where Tawe Flows' need not simply be read in negative terms (Goodby 2013: 283). 


\section{'WHAT THOMAS NEEDED'}

As he himself explained in 'The Caernarfon Court Speech', Saunders Lewis's political writings and political acts developed in part from his cultural and literary studies (Lewis 1973a edn: 115), and, without a doubt, one of his chief contributions in Wales was as literary critic and scholar, rediscovering and celebrating Wales's literary tradition in the 1920s and 1930s, when Dylan Thomas, of course, was emerging as a writer of 'English poems and stories' (Davies, P. 1973: 96; Thomas 1985 edn: 96). To an unfamiliar audience - and one is reminded of T. S. Eliot's remark in 1919, that 'you can hardly make the word [tradition] agreeable to English ears' (Eliot 1995 edn: 71) Lewis's seminal concept of Welsh tradition is best explained in his essay 'The Essence of Welsh Literature' (1973b edn), or in his short review of Alun Cilie's poetry, 'A Member of Our Older Breed' (1964a). Not to be confused with traditionalism, nor with 'the reassuring science of archaeology', as Eliot put it (1995 edn: 71), Lewis's 'tradition' is classical, contemporary and continuously creative, and it must not be misunderstood as an overemphasis on organic growth and unity, without room for spontaneity, variety or even revolt. In the 14th century, it enabled the genius of Dafydd ap Gwilym (fl. c. 1330-50), as it nowadays enables a young poet such as Rhys Iorwerth to emulate his success. It means that a Welsh poet today - whether his or her work is marked by a sense of originality or not-might employ the englyn or the cywydd, classic metrical forms of the Welsh Middle Ages (although originating as far back as the 6th century) as his or her contemporary mode of expression. Contemporary poets such as Twm Morys and Mererid Hopwood are therefore 'the heirs of Taliesin, of the court poets of Llywelyn the Great, of the country house poets of the 15th century gentry' (Lewis 1964a). 'The whole cultural world, in all its forms, exists through tradition', argued Edmund Husserl (1970: 354). This too was how Saunders Lewis defined the Welsh literary tradition: rooted, continuous and encompassing all, from Taliesin and Aneirin in the 6th century to the newest generation of contemporary poets. 'And all the intermediaries are involved' (Lewis 1973b edn: 155). In Lewis's magisterial view, its great literary tradition is what Wales had to rival 'the irregular richness and variety of Shakespeare and his countrymen' (1932: 5 my translation). On another occasion, he boldly ventured even further, asserting that ' $[\mathrm{t}]$ here is in European poetry only one thing that can compare with it, and this is The Divine Comedy of Dante' (1973b edn: 158).

Dylan Thomas, in a letter responding to Stephen Spender's review of his Collected Poems, once wrote: 'Oh, \& I forgot. I'm not influenced by Welsh bardic poetry. I can't read Welsh' (1985 edn: 855; cf. 24). There are other less well-known remarks, however, which suggest otherwise, and point to the fact 'that he was not quite as innocent about 
bardic techniques as he pretended' (Ferris 1999: 105). Indeed, one of contemporary Wales's most distinguished Welsh-language poets, Alan Llwyd, has even gone so far as to suggest that 'Dylan Thomas knew a great deal about cynghanedd and Welsh metres' (Llwyd 1978: 54). Nevertheless, until quite recently, the traces of cynghanedd, a specific form of strict-metre poetry in Welsh, that Llwyd and others claimed to detect were 'dismissed' by many critics (Ferris 1999: 104), partly as they could be explained by reference to the English poet, Gerard Manley Hopkins, who could not only read Welsh but write poetic exercises in cynghanedd (Davies, A. T. 1962: 117; Tindall 1996 edn: 11; cf. Llwyd 1978: 28). Hopkins was 'the one great and deciding influence on his work', according to Aneirin Talfan Davies (1962: 118) - though Thomas himself thought otherwise (1985 edn: 282, 297). And, of course, there is no denying his enormous debts to the great English romantics, especially Blake, and the metaphysical poets, most notably Donne, not forgetting, of course, the 20th-century context of Yeats, Lawrence, Eliot, Joyce and Auden (Kershner 1976: 107-91; Smith 2001).

Whether or not Dylan Thomas actually held a book of Welsh poetry in his hand, or asked a friend such as Davies or others, perhaps even his father, to explain either in general terms or in detail the metrical rules of cynghanedd to him, as it is claimed, is not really my chief concern (Davies, A. T. 1962: 118; Llwyd 1978: 54). Even if one ignores all the anecdotal evidence, Barbara Hardy is surely right to suggest that '[a] prosodic device like cynghanedd is easy to grasp in theory' (2000: 34), especially to a poet who lived in a country of 'eternal eisteddfodau' (Thomas 1985 edn: 145). Whatever the cause of the 'analogy' (Davies, W. 1986: 96-7), the similarities between Thomas's modernist poetry - his attitude towards words in particular - and the poetics of the Welsh literary tradition are clearly apparent to a number of his readers familiar with Cerdd Dafod and cynghanedd, i.e. the Welsh bardic tradition. In particular, it strikes me that a comparison might be made between Dylan Thomas's suspicion of 'the prearranged leaping together of words' and what poets of cynghanedd refer to as hen drawiadau - literally translated as old beats, i.e. clichés of cynghanedd. Any Welsh poet of originality will not only seek new combinations of words in order to form lines of cynghanedd, but also reject altogether those words and lines of cynghanedd which came easily not only to his or her mind but also to the minds of a hundred other poets. Dylan Thomas's ambition was 'artistic selection, new associations for each word' (1985 edn: 93-4), and 'freedom from the traditional corruptions of "taste" and "beauty"' (1985 edn: 274). What are rightly claimed as 'utterly modernist' traits in English poetry - evident in Thomas's 'insistence on the materiality of language and ... the autonomy he grants to words' (Wigginton 2001: 98) - are also aspects of traditional Welsh poetics. 
That tradition, sustained and celebrated at the National Eisteddfod, not only continued into the 20th century in the work of such beirdd gwlad as Alun Cilie-poets employing the classical forms of Welsh poetry in their various communities-but also enjoyed a renaissance following the establishment of the various Welsh departments of the University of Wales, where scholars such as Saunders Lewis rediscovered the literary past and its relevance to contemporary Wales. His literary mentor at Liverpool University, Professor Oliver Elton, had argued that literary criticism should mostly concern itself with 'what we think of Shakespeare and find in him, and what, after all, he is to us' (1907: 79). Though Elton valued 'the affair of textual editing, of linguistics, and of [establishing] the Shakespeare canon', literature, above all else, needed to be relevant and of use. In a similar vein, as he transported Elton's views from Liverpool to Swansea, Saunders Lewis read the medieval poets of Wales as if they were his contemporaries, and as if a civilised society in Wales could not be established without them.

At the time, many Welshmen and women, irrespective of the language of the home, knew very little about the literary tradition of Wales. The poems of the great medieval masters were simply not available, and, as Saunders Lewis suggested in 1932, it would take some time for the Welsh to develop that sense of métier which he and Eliot so admired in the French (Lewis 1932: 115; Eliot 1995 edn: 71). For instance, the work of the aforementioned Dafydd ap Gwilym, arguably Wales's finest poet, was not edited and published until 1952, a year preceeding Dylan Thomas's death in New York.

In reviewing that volume, Gwaith Dafydd ap Gwilym (Parry 1952), Saunders Lewis sought to explain to an English audience the poet's genius in comparative terms. Translating the opening lines of a poem, in which 'clusters of metaphors and fantastic simile' convey the wonders of a seagull, employed as the poet's love-messenger, Saunders Lewis suggests that the poetic appeal 'is as compulsive as Dylan Thomas for the English':

All Dafydd's themes seem to rise like Goethe's songs out of moments of experience, realize with swift intensity, accidents, and occasions for incandescence. At the very same time Petrarch was teaching all Europe a slow and measured pace for poetry, but Dafydd ap Gwilym's verse is as nimble as his imagery; his mind is all turned out to see, to hear, to be with the fox and hare and blackbird, to climb the sky with the skylark, in a rapture of entranced living. (1973c edn: 163)

Given that suggestive mention of Thomas, might Lewis here have been thinking, too, of the opening lines of 'After the Funeral' or 'Poem on his Birthday', or might he have had in his mind any number of Dylan Thomas's poems in which the poet employs 'clusters of metaphors' to convey a sense of 'swift intensity'? It seems, especially in 
translation, that Lewis, with the instincts of a creative writer as much as those of a scholar, might here be seeing and hearing the jouissance of Dylan Thomas in Dafydd ap Gwilym's verse - a curious example of what Harold Bloom has described as 'Apophrades, or the return of the dead ... as though the later poet himself had written the precursor's characteristic work' (Bloom 1973: 17; cf. Davies, A. T. 1964: 53). Could not this 'Seagull' by Dafydd ap Gwilym, have been viewed from Dylan Thomas's 'heron / Priested shore' (2000 edn: 86)?

Flashing gull on the full tide, Hue of snow or white moon, Speckless in loveliness,

Ball like a sun, fist of foam, Gaily-winged fish-swallower, There at anchor I'd have you float Linked hand with mine, sea lily, Like a paper glistening, A nun cresting the flowing tide.

(Lewis 1973c edn: 163; ap Gwilym 1952 edn: 313)

The English literary scholar, Frederick Bateson, similarly compared the poetry of Dylan Thomas to that of the 12th-century poet, Cynddelw Brydydd Mawr, seeing in 'the literal word-for-word translation' of a medieval poem 'the authentic flavour of the early Thomas' (1972: 226). Read in this comparative way, therefore, what often seems unique and peculiar to Dylan Thomas - 'the most poetical poet of our time' (Daiches 1966 edn: 14) — is wholly in keeping with the Welsh literary tradition: 'grandeur, generosity, and harmony' (Wain 1996 edn: 12). 'He had the ear', said Glyn Jones (1954: 24), 'the passion for words, the copious language, the endless patience, to have produced with astonishing effect in English the wonderful and unfamiliar music of the cywyddau'. Indeed, thinking again of Eliot's essay, 'Tradition and the Individual Talent', one could say of Dylan Thomas that it seems 'that not only the best, but the most individual parts of his work may be those in which the dead poets, his ancestors, assert their immortality most vigorously' (1995 edn: 71). His description of modern poetry as 'The Death of the Ear' in 1934, for example - 'this lack of aural value and this debasing of an art that is primarily dependent on the musical mingling of vowels and consonants' (Thomas 1971b edn: 166) - is as good a defence as any of cynghanedd and Cerdd Dafod, literally translated as harmony and the Poetry of the Tongue. His poetics in later years too, as explained in his letter to Harry Klopper in May 1946, stressed the importance of developing 'harmonically' not only 'the meaning of the words', but also their 'noise ... in the air and the ear ... their colours and density' (Thomas 1983 edn: 591). And critics generally agree that his 'most successful' poems 
are those in which 'the meaning, the imagery, and the form are all significantly affected by auditory affinities' (Moynihan 1966: 142). Most poets writing in cynghanedd will readily recognise Dylan Thomas's statements of poetics as their own.

In his reappraisal of Dylan Thomas's poem, 'The Conversation of Prayer', Bateson drew a distinction between the 'typically English conceit' of the poem's scenario and content and the Welsh metrical conceit of its style and form. 'The Conversation of Prayer' is loosely decasyllabic with an elaborate pattern of internal rhymes, and fearing that Dylan Thomas himself undervalued this particular poem-as he once remarked that the tools of the Welsh bardic tradition, 'assonance and alliteration and most complicated internal rhyming ... succeeded only in warping, crabbing, and obscuring the natural genius of the English language'-Bateson argued that '[w] hat Thomas needed, and never quite achieved in the loose or diffuse metres in which most English poetry is written, was a tighter and more verbally economical formal structure', such as the one employed in 'The Conversation of Prayer' (1972: 226). One might also point to the success of 'Do Not Go Gentle Into That Good Night', employing as it does the strict syllabic and rhyming pattern of the villanelle, capturing in nineteen lines the thanatophobia which imbues so much of Thomas's early work. One especially thinks of his Jarvis story, 'The Visitor': 'There was no to-morrow for dead men' (1983 edn: 25).

The classical simplicity of this great poem - comparable in its metrical intensity and tragic beauty to such a poem as 'Stafell Gynddylan', composed in the 9th century - suggests that Dylan Thomas would have not only made a wonderful writer of cynghanedd, as his friend Glyn Jones suggested (1954), but that such lines of 'assonance and alliteration and most complicated internal rhyming' would have felt most at ease within the metrical framework of the englyn, and the cywydd in particular, not to mention several other strict-metre forms of Welsh poetry, such as the decasyllabic hir a thoddaid. Though some poets, such as Alan Llwyd and Ceri Wyn Jones, have successfully married together cynghanedd and vers libre, most poets, in order for cynghanedd to flow as freely as a smoothing plane in a carpenter's hand (though at times it too might resemble a hammer), require the rhythmical strokes of a syllabically fixed metre and a structured rhyming pattern. In this regard, 'the limitation of form', to use Thomas's term (1985 edn: 25), i.e. the given structures of tried and tested metres, would, in my view, have enhanced Dylan Thomas's genius as wordsmith, whereas he himself believed that 'form should never be superimposed; the structure should rise out of the words and the expression of them' (1985 edn: 25). 


\section{CYNGHANEDD AND WRITING 'AWAY FROM WORDS'}

There are critics, such as Alan Llwyd, T. James Jones and Mererid Hopwood, who have sought out the perfect lines of cynghanedd in Dylan Thomas's poetry (Llwyd 1978; Jones, T. J. 2014: 236; Hopwood 2014). I too, reading his work as a poet of cynghanedd find it virtually impossible not to do so at times. My particular interest here, however, lies in Dylan Thomas's broader development as a poet and his general attitude towards the act of composition.

Being able to write lines of cynghanedd, or similarly, in English, having a gift for alliteration and rhyme, does not necessarily make one a poet, or at least not a very good one. Indeed, I remember a respected poet and critic once criticising an early poem of mine for being too good in terms of its cynghanedd. Only years later did I begin to understand what he meant. A decade of composition teaches a poet that cynghanedd is the poem's shape and colour, its chisel and its brush, but not the object per se, though, of course, the poem's form is nevertheless inseparable from its content, and might even be as dominant as colours on canvas (cf. Thomas 1985 edn: 12). Dylan Thomas too knew something of this predicament (Tindall 1996 edn: 17). In a letter to Pamela Hansford Johnson, he exclaimed: 'I'm a freak user of words, not a poet. That's really the truth' (Thomas 1985 edn: 130; cf. 389). In several perfectly crafted poems of power and eloquence, however, in both his early and later work, he undoubtedly overcame this conflict of form versus content.

Poetry, though it has its origin in wordplay, must be more than 'word art' (Crehan 2001: 49). A love of words, however, is as good a starting point as any other. It is certainly intrinsic to the Welsh literary tradition, past and present, both in cywydd and in vers libre. Cynghanedd developed as common aspects of speech and writing-i.e. rhyme, rhythm and alliteration - were foregrounded to formulate a poetical system, intended always for public performance and social appreciation. Its effect, therefore, is artistic pleasure and, in the hands of a master such as Dafydd ap Gwilym, cynghanedd, though in a sense a taught and acquired literary language, can be as familiar and subtle as the beautifully carved shape of a wooden chair. The wordsmith need not necessarily obscure the natural genius of his or her language, but rather she or he carves and shapes and fits its elements together in a new way, for in Welsh we talk of 'working' a poem—gweithio englyn — and not of warping. Of course, the poet's work is artistic and creative and, by means of metaphor and wordplay, he or she often makes strange the familiar. Welsh poets of cynghanedd, as much as any Russian Formalist, enjoy playing with words, syntax and expectations, but one need only read aloud the lines of Dafydd ap Gwilym to understand that the end result need not necessarily be obscurely ambiguous. As Aristotle noted in his Poetics, the poet strives 
for a delicate balance: 'what is needed is a mixture of these kinds of expression: the use of common words will produce clarity, and the use of exotic expressions (foreign words, metaphor, ornament, and the other items listed) will elevate the style above the vulgar' (2013 edn: 45).

Dylan Thomas's poetry, at its best-the poems selected by John Wain for his anthology of English verse, for example (Wain 2003 edn) - achieves this desired effect: appreciable craft as an integral part of an artistic and enjoyable object (cf. Thomas 1985 edn: 32). Consider, for example, the opening lines of his poem, 'O Chatterton', addressing as it does the namesake of this lecture series. There is no cynghanedd here, but the verse does exemplify the poet's love of individual words, rhyme, rhythm and alliteration. One feels its craft, its shape, and that the object, at least in these opening lines, has been worked at, nicely.

Like others before him-Shelley, Wordsworth, Coleridge, Keats - the penniless, morbid romantic in Dylan Thomas, living at Laugharne in 1938, saw in Thomas Chatterton's life a fable for his own sorry existence as a poet. Unlike the gifted teenager, however, dying of arsenic poisoning in his Brook Street attic, Dylan Thomas's chosen act of suicide was simply to live.

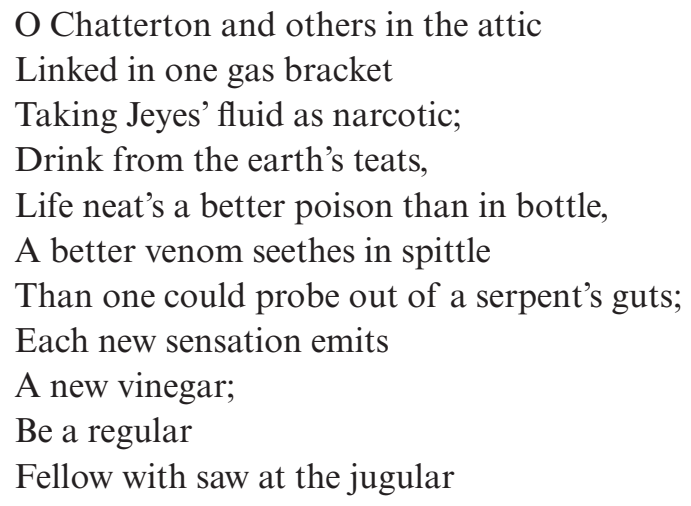

(1991e edn: 137)

Performing these opening lines anew, the fusion of new images and repetitive sounds compel the reader to delight in the poem as an object: in what it says, and how it says it. Allowing for the monosyllabic fist to the gut, which slows the piece entirely, the alliteration and rhyme carry the reader onwards, from line to line, throughout the series of vivid images: the 'clusters of metaphors and fantastic simile'. An English contemporary might have described coldly and 'in sickening detail' (Thomas 1985 ed: 22), the poverty in which Dylan Thomas lived and worked at Laugharne. Dylan Thomas, however, the 'smokeless and breadless' poet, described his 'pokey and ugly' cottage in his letters (Thomas 1985 edn: 304), choosing rather, in verse, to shape his poem in metaphor, from words. One imagines the poet consulting his famous wordlists, 
from which the alliterative and rhyming words are brought to bear on the subject, not too dissimilar to how some poets of cynghanedd nowadays regularly thumb their way through books of rhyme and alliteration ( $Y r$ Odliadur and Y Cleciadur), a process which, of course, is always open to abuse, when poetry is no more than 'stringing pretty words together' (Thomas 1985 edn: 78; cf. 592). Beginning with the famous image of Chatterton's suicide, which would surely have given him the alliterating 'attic', other words too, 'narcotic', and perhaps 'bracket', involve themselves in the making of the poem; similarly, from his word lists (on paper or in mind), 'jugular' must have come along with 'vinegar' and 'regular'; 'better', to alliterate 'bottle' and 'spittle' (which, when phonetically written here as if Welsh sounds-betyr, botyl, sbityl - are in complete cynghanedd). There is also the rhyming of 'neat' and 'teat', of course, which might have suggested, or have followed 'bottle' and 'spittle', if not from an initial formulation of words associated with drink and drugs. And so, though the poem is evidently about something else, and about something quite specific, addressing as it does the suicidal Chatterton, one senses that the poem has nevertheless been written from words, and has been crafted in a fashion not dissimilar to that in which a writer of cynghanedd might also craft a poem in the strict-metres, e.g. an englyn.

An example, perhaps, might help clarify the point. A recent short poem of mine, an englyn, began its life as a given word: 'Campese'. Commissioned to write the short poem of thirty syllables - four lines, sharing a single rhyme, in cynghanedd — I found that the consonants surrounding the accent in the subject's name 'Campese' suggested the words 'Pa eisiau?'-'What need is there?', i.e. Why him? And so the first line of the englyn was formed-'Pa eisiau rhyw Gampese?'- 'Who needs a Campese?' So too was the rhyming pattern for the four-lined englyn established. And so, in writing such a strict-metre poem, one often writes from rhyme, from possible end-of-line wordstaken from book or mind or subconscious - which in turn suggest possible images and meanings. In the case of the englyn written for the former Australian rugby player David Campese, the end result was as follows (with the cynghanedd here highlighted for the reader):

$$
\begin{aligned}
& \text { Pa eisiau rhyw Gampese? - Onid awch } \\
& \text { Yr holl dîm sy'n cyfrị?? } \\
& \text { Holwch bymtheg sy'n rhegi } \\
& \text { Camp a naid ein Campo ni. }
\end{aligned}
$$

The translation of the poem below (not strictly literal), is inevitably a different object to the englyn above, devoid of its cynghanedd and fixed syllabic structure, and written primarily from meaning. 


\author{
Why him, Campese? \\ Is it not a team's game? \\ Go and ask the fifteen there cursing \\ Our Campo's feat, our Campo's step.
}

The opening lines of 'O Chatterton' seem, at least from my perspective, to have much in common with the writing process undertaken in composing an englyn in cynghanedd. Although cynghanedd's home is the octovowelled and phonetical Welsh language-a, e, i, o, u, w, y $+\mathrm{h}$-Dylan Thomas's poetics as an English poet—his emphasis especially on writing 'away from words' (1985 edn: 122, 182) - is extremely familiar to a poet who might work at an englyn. Indeed, in placing 'regular' at the end of the penultimate line quoted above from 'O Chatterton', Dylan Thomas exaggerates the internal rhyme, and thus literally shapes, not only the sense with its sound, but also the object, the poem, before closing the stanza with one final, wonderful image: that of the poet living 'with saw at the jugular'.

David Holbrook criticised Thomas for his use of 'Roget's Thesaurus ... Brewer's Art of Versification or some other guide ... catalogues of synonyms' (1972: 127). These books, however, are nothing compared to the detailed grammars and the rules of cynghanedd produced by the professional poets of the Welsh literary tradition, not to mention the contemporary books on poetics and poetry, the Odliadur (a dictionary of rhyme) and the Cleciadur (a dictionary of cynghanedd) used by many writers of Welsh poetry today. Moreover, Holbrook fails to understand how such ready-made lists are used by poets of originality, and for what purpose. For when a poet uses such a list, he cares not that words have been 'dredged out of their context in which alone they have metaphorical life' (1972: 128), but rather that he or she, in combining one word with another, might actually spark a new context and create a new metaphor in his and her audience's mind: 'a new thing with new associations' (Thomas 1985 edn: 66). What Holbrook sees as 'mechanical poetry' is nevertheless a creative process (1972: 136), with the process of choosing words no more or less mechanical than a painter's methodical choice of colour for his or her pallet. This too is why the poet produces endless drafts of the same poem in making, for in so doing, he or she performs the poem in writing, allowing for the fact that changing one single word will change the colour and shape and feel of the whole object (cf. Aristotle 2013 edn: 46).

\title{
WILLIAM WILLIAMS PANTYCELYN
}

Written in 1938, and included in a letter to the critic, Henry Treece, 'O Chatterton' belongs to that period in Dylan Thomas's life, sometimes described as middle Thomas, 
when the 'freak user of words' sought to develop his craft as a poet. It is this aspect of his work which is primarily of interest here, and I would like to suggest a new comparison, not between Dylan Thomas and one of the classical poets of the Welsh literary tradition, but with the famous hymn-writer, William Williams, Pantycelyn, who, in some respects, is much closer to Dylan Thomas than Dafydd ap Gwilym or Cynddelw Brydydd Mawr.

Though the focus of this paper is on texts published in 1938, I should like to start here in Swansea-Abertawe in 1927. In Dylan Thomas's biographies, the year is remembered for being the one in which Thomas published a plagiarised poem in the Western Mail - a fabrication which would only come to light in 1971 (Ferris 1999: 38; Fryer 1993: 26-7).

At the other extreme, in the very same year, Saunders Lewis published an enterprising study of the great hymn-writer of the 18th century's Methodist Revival, Williams Pantycelyn (1927). The book's comparative reading was bold and original, reading the hymns and dramatic prose of Pantycelyn in relation to two things: (i) the Welsh literary aesthetic, developed by the professional poets in their medieval grammars and schools; (ii) the new psychology of Freud and Jung. Concerning himself primarily with the difference between romantic and classical poetry, the author analysed the journey of growth which Pantycelyn undertook as a poet. And intriguingly, that analysis seems wholly applicable to Dylan Thomas.

Rereading the book, even today, there is a sense of excitement and illumination in the air, as one is persuaded that Pantycelyn, along with Rousseau in France, is the founding father of the Romantic Movement in Europe. I imagine that it is difficult for some to appreciate the claim. The hymn, as a genre, especially in England, is undervalued. Charles Wesley and John Newton are studied by theologians or historians, not literary critics, and such notable literary achievements as Wesley's 'Come, O Thou Traveller' are rarely anthologised, though inferior secular poems will happily be selected (cf. Davies, P. 1973: 93-4; cf. Ferguson et al. 2005, which does include two hymns by Charles Wesley).

Saunders Lewis, however, having studied the English Romantics at university, saw from this perspective that the hymn-writers 'Williams Pantycelyn and Ann Griffiths are for [the Welsh], what Blake and Wordsworth are for the English, what Manzoni is for the Italians' (1965: 9). Not only in Pantycelyn's hymns, but also in his dramatic poetry and dialogue prose, he saw the 'grandeur and intellectual power' of 'major poetry'.

The young Dylan Thomas, a regular chapelgoer as a young boy, would have read and sung Pantycelyn and a host of hymns, in English, and during his stays at Fern Hill, in Smyrna chapel, Llangain, in Welsh (Jones, T. J. 2014: 228; Thomas 1985 edn: 29). In the 1949 broadcast 'Living in Wales', he recalls '[t]he tinroofed chapel where I 
trebled "Aberystwyth" and made calf eyes at the minto-sucking girls' (1991c edn: 204); and in his story, 'The Peaches', his portrayal of the preacher cousin Gwilym draws upon this world of the Welsh chapel in Llangain:

I sat on the hay and stared at Gwilym preaching, and heard his voice rise and crack and sink to a whisper and break into singing and Welsh and ring triumphantly and be wild and meek. (1983 edn: 128)

Here, it seems that the author, in reworking his memories into art, is translating an originally bilingual scene. The Welsh element is reimagined and made accessible to the adult author and English reader. The exchange, therefore, between the cousins, breaking into Welsh, would have been thus:

$O$ Dduw, God, Thou art everywhere all the time, in the dew of the morning, in the frost of the evening, in the field and the town, in the preacher and the sinner, in the sparrow and the big buzzard. O God, O Dduw, fe weli di bopeth a wnawn ni; gweld yn $d d w f n$, yn ddwfn i'n calonnau; ein gweld ni, dan y blancedi, under the blankets, a ni'n cysgu'n drwm, yn y cysgodion erchyll a'r nos yn ddu bitsh, pitch black. O fe weli di bopeth a wnawn ni, $O$ Dduw, yn y nos a'r dydd, yn y dydd a'r nos; popeth, popeth. Everything. O Mae dy lygad di arnom ni yn wastadol. O Dduw. God, mun, you're like a bloody cat. (1983 edn: 128; my translation.)

(In this one aspect, in terms of humour, one has to say that Dylan Thomas has more than an edge on Saunders Lewis, whose attempts at comedy as a playwright do not come close to the theatrical grandeur of his Racinian and naturalist tragedies.)

In literary terms, even when allowing for 'the curious reluctance of English critics to consider hymns as literature at all' (Davies, P. 1973: 94), it is surprising what little attention this element has received from the biographers and critics, especially as Dylan Thomas himself listed 'a few lines of hymns' as one of the influences on his creative imagination in his 'Poetic Manifesto' (1971a edn: 157). The Wales of his time was indeed one 'hymnal blob' (1985 edn: 767).

Following perhaps Thomas's lead in the 'Manifesto', some have rightly shown 'the profound influence of the Bible upon the poet's work', but the hymns too were essentially 'part of his life' (Davies, A. T. 1964: 30-1; Moynihan 1966: 18-20, 219). Critics choose the boy in his father's library, reading Blake and Wordsworth and Hopkins, and forget the one sitting and standing by his mother, or his aunt and cousin, caressing and reading and singing these hymns in chapel week after week, year after formative year.

The Romantics aside, Barbara Hardy compares Thomas's strong beginnings and endings to those of Shakespeare and Joyce, but much of what she has to say about Thomas's sense of 'climax' and 'conclusion', his 'action-packed images', not to mention the poetry's 'microstructures which are unified within themselves' seem 
applicable to the literary structures of the stanzaic hymn (2000: 33-4). As a welldeveloped, communal genre of praise poetry, the hymn is both rhythmical and syllabic - untitled too, as were Thomas's poems - and delivers not only a sense of flow from line to line, but also emphasises monosyllabic and sonorous words, which Thomas, of course, so admired. Critics concede that his poetry '[owes] something to Welsh hymn-singing and the hwyl of chapel sermons' (Goodby 2013: 71; Price 1953: 37-9), and so a study of Thomas's poetry in relation to the Congregational hymnbook might prove more illuminating than expected. The biographers and literary critics too might consider how the hymn especially would have taught Thomas that poetry need not necessarily be 'socially and politically committed' in order for it to be powerful and of use to people (Davies, W. 1986: 45). To quote from his documentary script, 'Green Mountain, Black Mountain': 'the singing in the chapel is never grim or grey', but rather 'sweet and powerful, wild and gentle' (Thomas 1995a edn: 30; cf. Thomas 1985 edn: 77). Might not Thomas's poetry too be described as such?

Pantycelyn's most famous hymn in English is undoubtedly, 'Guide me, O! Thou Great Jehovah', also sung as 'Guide me, O! Thou Great Redeemer'. It has been sung in the smallest of chapels and the largest of cathedrals, in vestry prayer meetings and at state funerals and weddings. As a remnant of the non-conformist past, it is still heard at rugby internationals in Cardiff, somewhere between Tom Jones's 'Delilah' and Max Boyce's 'Hymns and Arias'. For the purposes of this paper, it will serve as an example.

Guide me, O Thou Great Jehovah, Pilgrim, through this barren land;

I am weak, but Thou art mighty;

Hold me with Thy powerful hand:

Bread of heaven!

Feed me till I want no more.

(Williams, W. 1855 edn: n. 660)

In such a verse as this one, Saunders Lewis sees the romantic poet, concerned only with fulfilling his own desires, his own wants, his own needs. Though it might be sung by a large congregation of people, at the time of composition - 'yn awr y cyfansoddi'the poet's focus is entirely on his own experience (1927: 29). 'Guide me ... Feed me, till I want no more'.

Had Saunders Lewis written the book a decade later, in 1937-though, of course, he was in prison that year-he might have compared Pantycelyn's verse to that of Dylan Thomas. For not only is the book full of references to Rousseau and Wordsworth, but Saunders Lewis compares Pantycelyn's imagery to that of the modernist, James Joyce (1927: 143, 116). 
Lewis notes that, in his epic poem, Theomemphus, Pantycelyn foresaw and foretold the strangest things in Joyce. He might as easily have said that much of what is new in Dylan Thomas-his fluids, his body, his overflowing senses and fears, his obsessions and growth, his sexual wants - is present too in Pantycelyn's Theomemphus, for it is all about the temptations of a young Christian (Williams, W. 1964 edn: 193-399). And Pantycelyn's prose dialogue, Ductor Nuptiarum [the Wedding Councillor], is a conversation between two women on sex and loveless marriage (Williams, W. 1967 edn: 243-303).

Whether or not Dylan Thomas knew about Theomemphus and Ductor Nuptiarum, he was certainly familiar with Pantycelyn's entries in the Congregationalist hymnbook, and such verses as the one quoted above might have influenced his deployment of Christian and romantic imagery, as well as his general sense of poetical structure and narrative climax. The bilingual Pantycelyn, then, is another important tangible link between the two authors under consideration here. Dylan Thomas's father, a learned man of letters, who gave not only English lessons at the grammar school but also Welsh tutorials at his home (Fryer 1993: 6), might very well have read Saunders Lewis's Williams Pantycelyn, and would, one imagines, as an agnostic, have particularly enjoyed the way in which the sacred texts of the Welsh chapel were being read as literary compositions.

\section{A DE-PART TOWARDS BEING}

There is broad agreement that Dylan Thomas's verse falls into two periods, with, perhaps, a transitional Thomas bridging the two. Elements of the early poetry continue throughout, and one can read in the other direction also. Some have sensibly warned that 'conclusions about development must be cautious; for he took one step back for every step forward - and one step sideways' (Tindall 1996 edn: 20), but the classification is still useful. The early verse is inward, intense and personal, though the voice is somewhat removed, aware of its own power and authority. There is a fascination with wombs and birth, death and bodily fluids, and with the poet's journey of growth. $\mathrm{He}$ is aware of nature's drive and rush, but its elements - light and water and wind - are a source of inward inspection. And sometimes, just as the 'Bread of Heaven' is consumed by Pantycelyn's 'me', or as Pantycelyn himself is symbolised by the sun, the earth and the planets (Lewis 1927: 73), the external world is internalised by Dylan Thomas's own body. 'Into the sea of yourself', he implored Trevor Hughes (1985 edn: 17; cf. $39,90)$. The waters are the waters of his heart. 
Light breaks where no sun shines

Where no sea runs, the waters of the heart

Push in their tides;

And, broken ghosts with glow-worms in their heads.

The things of light

File through the flesh where no flesh decks the bones.

(2000 edn: 23)

Saunders Lewis might have said that this is Theomemphus once again, for Theomemphus too, in his second-birth, sees the terrors of sin as a great flood, confusing and deceiving his senses (1927: 144).

Before the works of Freud and Jung, what Pantycelyn achieved for Welsh in the 18th century was a new scientific language, expressing - and I quote Lewis in translation here- 'the complex confusion of life's most deceiving experiences, lust and desire, the ebb and flow of nervous feelings' (1927: 220). Rather like Pantycelyn too-accused, or rather praised, by Saunders Lewis for overloading his lines (1927: 221) - there is, at times, a sense of exuberance in the early poetry of Dylan Thomas; so much so, that the young poet, $\grave{a} l a$ the romantic hymn-writer, cannot find the words to express his feelings.

The force that through the green fuse drives the flower

Drives my green age; that blasts the roots of trees

Is my destroyer.

And I am dumb to tell the crookéd rose

My youth is bent by the same wintry fever.

(2000 edn: 13)

There is 'nothing uglier in life than a sensible young man in control of his desires'. That is one of Saunders Lewis's great lines in his study of Pantycelyn (1927: 150). To many a critic and reader, the sheer power of Dylan Thomas's early verse remains the high point of his career as poet. The poems seem to capture the sexual turmoil of his teenage years in the most powerful and captivating way (Goodby 2013: 239; Mathias 1954; Olson 1966 edn).

There are others, however, who see in the later poetry a more developed and mature poet, rid of 'obscurity or esthetic failure' (Moynihan 1966: 119). This, perhaps, has led to a 'selective view of Thomas's writing' (Goodby \& Wiggington 2001: 7), and even to 'a misrepresentation of Thomas as solely a "Regional Romantic"' (Wiggington 2001: 102), even though the power of the early verse, as evidenced briefly by the above quotations, remains compelling.

That 'misrepresentation' has to do with poetic accessibility and with the enduring popularity of a few great poems, especially 'Fern Hill' and 'Do Not Go Gentle Into 
That Good Night'. At the risk of generalising, one might note that the later verse, while still extremely personal - indeed, confessional at times - is more social, landscaped and meditated, and after 1944, an accessible pastoral poet emerges, in such poems as 'Poem in October', 'Over Sir John's Hill' and of course, 'Fern Hill' itself. As suggested by such poems as 'Once It Was The Colour Of Saying', 1938, there is also a transitional Thomas, searching for a new voice. Consider, for example, this line from the poem:

The gentle seaslides of saying I must undo. (2000 edn: 74)

This denotes a subtle change in attitude in the poet's mind, or at least a readiness to commit to an earlier desire for a 'larger, wider, more comprehensible, and less selfcentred' verse (Thomas 1985 edn: 77). The poet, no longer content with being 'a freak user of words', considers how once 'a word of many shades' - though 'a lamp of lighting' for himself, the poet, 'the poor in the dark'-might now become more substantial, and less about himself:

Now my saying shall be my undoing,

And every stone I wind off like a reel.

Whereas ' $[t]$ he gentle seaslides of saying ... / . . charmingly drowned' the poet's interaction with the external word, he is now a fisherman, reel in hand, committed to catching all that is real. Walford Davies is surely right to see in the 'stone' image a readiness to put aside the poet's aesthetic wordplay and to consider rather 'the outside realities of people': 'The stone previously thrown at the scorned lovers in the park has now become either the bait or the weight on the "reel" with which he plans now to draw them out' (1986: 12-3). The 'freak user of words' senses that clever wordplay is not enough. He wishes rather to be a poet. This sense of juvenile exuberance-i.e. the poet's initial delight in the tools of the craft-so crucial of course to learning the tricks of the trade, also plagues his sense of real significance, and it is doubted deeply in transitional Thomas.

In his rich study of Federico García Lorca's early poetry, D. Gareth Walters talks of the poet's 'dissatisfaction with the easy but shallow gifts - the false gems - and a determined ... intent to achieve a goal that is unknown' (2002: 82). So too in Dylan Thomas:

The lovely gift of the gab bangs back on a blind shaft. (Thomas 2000 edn: 78)

In Welsh, I have suggested 'r/hanfodoli' as a name for this process, which might be translated as a 'de-part towards being' (Hallam 2012). The poet, in disbelief, panics and condemns all that she or he has achieved thus far before resolving and reaching out in hope for a voice in poetry and in life. The poet has to 'wrestle out and 
unravel in a panic' (Thomas 1985 edn: 915-6). She has to de-part herself and depart anew.

While the poem 'Once It Was The Colour Of Saying' takes this 'de-part towards being' as its subject-matter, Dylan Thomas's most prominent depart poem-i.e. the poem in which the new critical standards are realised and in which Thomas's new 'reel' is cast - seems to be the powerful elegy which he crafted in memory of his dead aunt Ann, in 1938, 'After the Funeral'. Revisiting a poem which he had started years earlier after her death, the poet discovers a new depth of understanding, a new modesty, an appreciation of her, which had previously eluded him. This love for another, this praise, changes the poet. Those three simple words, 'I, Ann's bard', suggest a new poetics for Dylan Thomas: a me-you aesthetic in which the poet's words are used as bait to capture the beauty of his aunt's life. It is there again in the final stanza of 'Do Not Go Gentle Into That Good Night': 'And you, my father' (2000 edn: 148). It is, of course, reminiscent of the poet-patron relationship so integral to the Welsh literary tradition, and which Dafydd ap Gwilym redefined in relation to his lovers: 'Prydydd $i$ Forfudd wyf fi' ['I, Morfudd's bard'] (ap Gwilym 2007 edn: poem 119).

In 1933-4, when Dylan Thomas hits the literary scene in London, one might refer to him in terms of Kierkegaard's existentialism. He's unique. He's fresh. He's different. He shocks the scene, 'a man with originality ... and everything comes to life' (Kierkegaard 1965 edn: 247). Three of London's best, T. S. Eliot, Stephen Spender, Geoffrey Griegson, want to publish his work. The transitional Thomas, however, senses with Sartre and Heidegger, that in order to be, one needs to be with others (Sartre 1958 edn: 104; Heidegger 1993 edn: 156).

This me-you aesthetic of 'I, Ann's bard'-also there in some of the early poems, 'I See The Boys Of Summer', for example (2000 edn: 7)—now dominates Thomas's sensibilities as a poet. Walford Davies senses for the first time 'a new style' emerging: 'a more deliberate economy of articulation ... a hard clarity of perception' (1986: 66). It is there too in the elegies, during the Second World War, though the sense of belonging to a person, to her way of life, to her parlour, to her Welsh hands, is less apparent. Gone is the Dylan who once remarked: 'There must be something lacking in me. I don't feel worried, or hardly ever, about other people. It's self, self, all the time' (Thomas 1985 edn: 13).

Walford Davies sees in Dylan Thomas what Saunders Lewis sees in Pantycelyn, what D. Gareth Walters sees in Lorca, what Helen Vendler sees in Keats and others (2003), what I see too in the work of contemporary Welsh poets in their thirties: Aneirin Karadog, Hywel Griffiths and Eurig Salisbury (Hallam 2012). 'The gentle seaslides of saying' are undone. This seems to be a shared human experience for poets in various cultures and languages. It is similar, perhaps, to teenage growing pains, or 
a mid-life crisis. It has to do with human unease and with our ability to look back and to look beyond ourselves: 'the fierce tears of existential rage' (Maud 2003: 79). However, whereas middle-aged men and women approaching their fortieth year often want to extravagantly indulge themselves, poets often only want a deeper, simpler and more developed voice.

As with Dylan Thomas's depart poem to his aunt, not to mention the wartime elegies, it was the same genre, the elegy, which changed Pantycelyn too (Lewis 1927: 202). In his experience, in 1766, it ushered in a new readiness to contemplate, not his own want and need for the Bread of Heaven, but the Bread itself, the Giver of life, and what He, God, is to him: what they are together, in love. Where before there was introversion, there is now extroversion, as the poet describes the object of his affection, not his affection. He wanders outside himself- 'allan ohono'i hun' (Lewis 1927: 72) - and focuses his gaze on Christ, singing praises only unto Him: 'Now my saying shall be my undoing'. It is this extroversion of thought, borne out by the task of writing elegies, that gives Pantycelyn, the hymn-writer, a new desire for external reality and an interest in nature. To Saunders Lewis, the romantic mind of Pantycelyn draws closer to the Welsh aesthetic of the classical, professional poets of the 14th and 15th centuries: closer to the Taliesin panegyric tradition of praise and patronage. The poet of the 'barren land' now sees the value of society, of the external world; and though a romantic to the very end, the introversion and extroversion now combine to deliver Pantycelyn's mature verse (1927: 236-7).

A similar development is very much apparent in Dylan Thomas's verse, i.e. as he becomes 'Ann's bard'. And as he looks across the estuary in Laugharne 'more clarity' is achieved (Moynihan 1966: 64) as the work 'becomes clearer, less "clotted" with word and image, and more obviously narrative' (Kershner 1976: 221). As in his prose, so too in his poetry: 'The first person can be forced out of self-occupation, to observe ...' (Hardy 2000: 88). The poet moves towards others as in 'Do Not Go Gentle Into That Good Night', or towards an external view of his own past as in 'Fern Hill'. And as the poet undoes 'the gentle seaslides of saying', critics have noticed the change in the number of compound words, polysyllables and propositional phrases, as 'the poetry seems to flow ever more easily' (Moynihan 1966: 128). Acquiring a new regard for the external word and a 'growing interest in people' (Stanford 1954: 169), both as poetical subjects and as members of radio's immediate audience, Dylan Thomas's development as a poet thus mirrors the path undertaken by William Williams, Pantycelyn. Indeed, there is much in Walford Davies's study of Dylan Thomas and Saunders Lewis's of Pantycelyn that is similar and interchangeable, even to the point where replacing the name of Pantycelyn with that of Thomas, especially in Saunders Lewis's last chapter, makes more or less perfect sense. 


\section{'HE BELONGS TO THE ENGLISH.' AND TO THE WELSH?}

As already mentioned, the depart poem, 'After the Funeral', was written in 1938. John Goodby describes it as 'a staging-post between the "green fuse" of 1933 and the later pastoral mode' (2013: 289). That same year, 1938, Saunders Lewis delivered his lecture, 'Is There an Anglo-Welsh Literature?' Is there a classification of Welsh literature, in English?

His answer was 'no', for several reasons, though he deemed it possible for an individual to be an Anglo-Welsh writer; to write, in English, for Wales. In 1938, in Saunders Lewis's mind, Dylan Thomas is not such a writer. He writes out of the English tradition, and for the English (1938: 4, 7, 12). And so Saunders Lewis delivers his infamous verdict, the cursing in my paper's title: 'Mr. Dylan Thomas is obviously an equipped writer, but there is nothing hyphenated [nothing Anglo-Welsh] about him. He belongs to the English' (1938: 5).

The young Dylan Thomas, so keen to leave 'the ugliness of the Welsh people' behind him, might have thanked Saunders Lewis for that line. Others too have suggested the same thing: that Dylan was always looking to London, and not to Wales; that Swansea at the time was closer to London than to Cardiff, not to mention Llansteffan (Tindall 1996: 11; Kershner 1976: 173). (Cardiff, of course, or Caerdydd for that matter, at the time, was not the capital city it now is, was not a capital city at all, and in the 1930s the literary man's train from Swansea went only to London.)

Each time one reads in the biographies and in the letters of how D. J. Thomas, the English grammar school master, read Shakespeare to his young boy, is not the same thing implied? That Dylan Thomas had been Shakespeared before he could even say 'bore da' (Fryer 1993: 8, 17; Thomas 1985 edn: 674-5). Though his mother and father spoke Welsh, they too knew that they belonged to the English. Not only did they live in the shadow of the Blue Books of 1847, but also, subsequently, of the Education Act of 1870. In Saunders Lewis's play, Merch Gwern Hywel (2000b edn: 657-704), first composed as a 'romantic history' in 1964, Rev. John Elias declares that 'the Methodists of Wales are the King of England's most loyal subjects. England is our country' (2000b edn: 660, my translation). D. J. Thomas, born some thirty-five years after John Elias's death, would, in socio-political terms, have had no reason to think otherwise. It was his nation, Wales, that belonged to the English, not the poet-son per se. Even I remember, as a boy, reading in an encyclopaedia: 'For Wales, see England'.

The language used by Saunders Lewis in his infamous sentence- 'He belongs to the English' - in a way, mimics the heightened language used by the English visitors and writers of the Blue Books of 1847. The government-commissioned Blue Books, a report on education in Wales, described the Welsh in dismissive and negative terms, 
presenting 'an image of the language as irredeemably harmful and dangerous' (Roberts 2011: 204), responsible for keeping them 'under the hatches', like slaves (I, 7; in Roberts 2011: 205). Such talk, of course, seeks an 'emotive' response (Roberts 2011: 204), and may lead to both assimilative and radical reactions (Williams, D. G. 2012: 27-8). So too does Lewis's sentence.

In defence of Dylan Thomas, even in 1938 there is evidence of his genuine interest in the Welsh medieval legends, 'the fantastic world of the Mabinogion', especially as a model for Anglo-Welsh writers (1932: 8), exemplified, perhaps, by his own stories set in the Jarvis Valley (Goodby 2013: 241). There is also, of course, his involvement in setting up the periodical, Wales (1985 edn: 358, 395), and his interest in being a member of 'a literary society in Wales' (Thomas 1985 edn: 387-8). Thirdly, one thinks of Thomas's return, not only to live in Wales, but more specifically in Laugharne, 'the strangest town in Wales, where the people speak a broad English accent ... surrounded by hundreds of miles of Welsh country', far away from the industrial valleys (1985 edn: 135). This, at least to Saunders Lewis, was the ideal for an Anglo-Welsh writer, in need of a good Welsh dialect (1938: 7-10); and Thomas was obviously in agreement. And finally, in Dylan Thomas's defence, there is also the fact that what the English found most fascinating about his poetry, was not its traditional style, but rather the oddity of its language, its self-reflective and sculptured nature. It is not surprising that Saunders Lewis in 1938 did not quote from Dylan Thomas's poetry in his essay, for, as he himself suggested in his later review of Dafydd ap Gwilym, Dylan Thomas's poetics - particularly his art of writing from words and not towards them - is very much in keeping with the aesthetic of the Welsh literary tradition.

In his study, Williams Pantycelyn, having explained that poetry was solely and soulfully a means of expression to Pantycelyn, Saunders Lewis explains that the hymn-writer knew nothing of his own country's Welsh aesthetic. He was ignorant of the complex and developed poetics which had reached its high point in the bardic grammar schools of the 14th and 15th centuries. He knew nothing of Dafydd ap Gwilym's genius as a poet.

Whereas poetry for Pantycleyn was a mode of expression, the Welsh bardic grammars stressed that a poem was rather a crafted object, a thing in itself, a work of art, and each word had to be treated with respect. 'Astudio geiriau a'u caru', is how Saunders describes the poet's work: 'to study and to love words' (1927: 32).

While Saunders Lewis saw no love of words in Pantycelyn, it abounds in Dylan Thomas. Indeed, for him, poetry is no more, and nothing less, than the 'setting down of delicate but usual emotions in a few, wellchosen words' (1985 edn: 25). Words must be weighted and selected, for 'there is always only the one right word' (1985 edn: 25). For his readers and critics too, his poetry is remembered primarily for its word-power, 'its energy and inventiveness, its metaphorical nature, its revelling in 
sound effects, its religious reverberations, its self-conscious, bardic narrator' (Gramich 2004: 240). To some authors, more interested in Dylan Thomas's biography and psychology - I think especially of Holbrook's study of the 'schizoid individual' here-it seems 'extraordinary to what extent critics of Thomas have failed to see with what strange mechanical perverseness he picked the life out of his own language or worked it up in an external way' (Holbrook 1972: 125-6, my italics). As already noted, this is exactly the same phrase which the Welsh medieval poets used to best describe their work: gweithio englyn - work it up. The fact that Holbrook uses the same phrase suggests that Dylan Thomas's approach to poetry, was, if in any way 'perverse', wholly in tune with those of the classical poets of Wales; masters such as Dafydd ap Gwilym, Guto'r Glyn and Tudur Aled, whose bardic grammars concerned themselves not only with cynghanedd but also with social morality. What Dylan Thomas at times lacked - though he too, of course, used regular stanzaic forms (Llwyd 1978: 54; Goodby 2013: 74, 80) — was not these Welsh poets' love of words and of grammar, but rather their fixed metrical forms and their face-to-face encounters with their learned audiences, i.e. the poetic and social framework in which his talents as a wordsmith might have flowed more freely. What he had in common with them, was a bicultural sense of flux.

Whether or not Dylan Thomas had read a particular book of Welsh poetry, had read the lists of rhymes in Geiriadur y Bardd: Yr Odlydd Cyffredinol (as he had read English rhyming books), had seen at the eisteddfodau Welsh poets working up an englyn, or had even discussed cynghanedd with Aneirin Talfan Davies (1962: 118; Thomas, M.W. 2014a), his whole world in Swansea-Abertawe was imbued with a sense of dualism between English and Welsh.

A biographer in search of empirical evidence might look at how Dylan Thomas's unusual middle-name, Marlais, became, in cynghanedd, 'Moreorless', as he played at radio broadcast with his friend Daniel Jones (Ferris 1999: 43), but, apart from such a particular instance of cynghanedd in Dylan Thomas's life, I would suggest that the strangeness of one's 'unusual name' (Thomas 1985 edn: 25) to English-speaking friends and neighbours is as strong a force as any in helping a young poet realise the arbitrary nature of the relationship between signifier and signified in any languagethat something is 'a thing and a word at the same time' (Thomas as quoted by Reid 1960: 54), pronounced both as 'Dullan' and 'Dillan' (Ferris 1999: 19). (And of course, one is repeatedly asked, not only how one's name is pronounced, but what does it mean, and what might it be in English, stressing the oddity of one's name and existence.) Nevertheless, though unusual and otherly, Dylan Thomas would not have been able to escape the cultural associations of his name - no more than Shakespeare's Romeo and Juliet or Arthur Miller's John Proctor, for that matter. 'Poor Dylan, poor him, poor me', he once remarked in self-pity - the thoughts of 'a Welsh poet' in 
Ireland, 1935, 'out-of-home'. 'But I wouldn't be at home if I were at home. ... This is an essential state of being': familiar detachment, home and away (Thomas 1985 edn: 190-1). Interestingly enough, he and his wife also chose a 'militantly Welsh' name for their firstborn, Llewelyn, who was - why do I feel the need to say 'of course'? educated 'in England' (1985 edn: 363, 903).

One might consider also that the poet's joy of language might have something to do with the fact that English was his parents' second and acquired language, and that they, quite (un)naturally, of course, passed on to him their joy of discovering and using new words, so that English, for their son too, in a way, was a strange-familiar friend, a language in which he felt both at home and somewhat removed. His experience was not too dissimilar to how cynghanedd is simultaneously a comfortable and creative language for any accomplished strict-metre poet in Welsh (Llwyd 1978: 58), for whom the technical rules of corresponding alliteration and rhyme are not in any way restrictivethough he or she, like Dylan, might sometimes 'write at the speed of two lines an hour' (Thomas 1985 edn: 51) - but rather a sure way of encouraging play and discovering possibilities. This sense of standing both inside and outside the English language is noticeable in so many of Dylan Thomas's letters, when he remarks, for instance, 'what a curious word that is' (1985 edn: 7); and in his broadcast 'Living in Wales', he talks of 'rolling the word Wales round my tongue like a gobstopper of magical properties' (1991c edn: 203). And in the other direction too, it is quite evident that he, a speaker of English and of 'broken Welsh' (1985 edn: 29), could but enjoy the joyous sounds of such Welsh place names as 'Gwaun-cae-Gurwen', which were likewise both strange and familiar, and all about him (1985 edn: 63). 'I've been staying all over the place ... Aberystwyth ... the Gower Peninsula, and in a cottage in Carmarthenshire, glorying in the name of Blaen Cwm' (Thomas 1985 edn: 174). And finally, on the subject of Thomas's dualism, one also thinks of his Welsh-speaking family, and how a predominantly passive bilingualism might have actively contributed to the joy of words expressed in his 'Poetic Manifesto': 'What the words stood for, symbolised, or meant, was of very secondary importance; what mattered was the sound of them as I heard them for the first time on the lips of the remote and incomprehensible grown-ups who seemed, for some reason, to be living in my world' (1971a edn: 154).

Might a comparison here strengthen the point I am trying to make? Not knowing whether Dafydd ap Gwilym in 14th-century Wales could actually speak or read Anglo-French with complete fluency (Edwards 2007: 13), does not deter the critic from appreciating what is all too evident - that he, as a Welsh poet, introduced to Welsh poetry literary conventions which were already prevalent in other European languages, and that poetry in Wales benefitted from a time of 'multifarious and robust confusion', when 'Anglo-French and Middle English and Welsh were cheek by jowl in the Welsh Marches and Crown Lordships' (Lewis 1973c edn: 160-1). The same might 
be said of Shakespeare's work and the fluidity of the English language in his time, i.e. that the language's lexical instability aided the poet's creativity (Davies, W. 1986: 100). Poets seem to revel in flux. How did Dafydd ap Gwilym come to combine the new 'art of Ovid' and the Welsh panygeric tradition? 'Let us say', suggests Saunders Lewis, 'that it was all around him' (Lewis 1973c edn: 161).

Though Florence Hannah and D. J. Thomas, the English grammar school master, famous for reading Shakespeare aloud to his son, had given their son a curiously Welsh literary name, they chose to raise him and their daughter, Nancy, in English. What other choice did they have, especially the father, the agnostic school teacher of English? Welsh, a language fit for eisteddfodau and chapels, had no real credence in the educational and political system. It existed only as a signifier in isolation, a thing in itself, a signifier with no signified, no relevance, no power, as if not of the world per se.

Saunders Lewis sought to give the parents of Wales a socio-political context which would be as Welsh as the name which D. J. Thomas chose for his English-speaking son. In the censored address of 1930, he explained that language and literature are always socio-politically combined:

Even the mere existence to-day of a distinct Welsh culture and of national institutions of any kind implies that Wales had once a political entity also, and whether we know it or not we are the heirs of that past. You cannot artificially encourage the language and literature and arts of a people and at the same time refuse them any economic and political recognition. The thing isn't possible. Literature and the arts are a function of social life, of political life, that is to say. (Lewis: 1930b, 5)

Saunders Lewis's legacy is his commitment to developing the political life of the Welsh nation and its language. He and others embarked on this venture in earnest in 1925, believing that 'there is something worse and more tedious than the death of a language, and that is its functionless survival' (1930b: 5). Though Dylan Thomas's parents felt they had no choice but to raise their children as English monoglots, others believed that establishing Welsh as the official language of Wales was entirely a plausible objective (Lewis 1933, 1985 edn: 61-5). Within the next ten years, their first victory would see the establishment of what is now known as BBC Cymru/Wales, one of centenary Thomas's chief supporters (Lucas 1981: 40).

In studying Dylan Thomas's work and that of his critics, it seems to me that his love of words, his crafting, is one of the main reasons, if not the main reason, why Thomas is often accused of being a pretend poet: a clown, a trickster, of having the gift of the gab, a stringer of words. There are other reasons too for the accusation, including a general suspicion of Welshness (Davies, J. A. 2001: 161; Wain 1965: 14; Goodby \& Wigginton 2001: 6, 9), his drink and lifestyle, of course, his lies and deceit, his own big, sonorous voice (silencing the reader's), along with a need in some critics 
to judge Under Milk Wood as a theatrical work, which, evidently, this particular play for voices is not. On stage, it simply lacks classical depth and intensity.

Thinking back to 1927, and to the plagiarised poem, 'His Requiem' by Lilian Gard, it is interesting that the biographers interpret the poem as evidence of a character flaw and a failing which emerges again and again in the poet's adult life, inevitably infecting his poems. To quote Paul Ferris:

There is a feeling that at times he is more interested in proving himself a poet than in getting on with the business of conveying whatever it is that he wants a poem to convey. The desire to display himself to the world as an artist was very real to Thomas. He did it in his life and his work. His poems are thick with the affectations of poetry. It is hard to avoid a suspicion that one of the forces that drove him was the desire to be a poet: perhaps, to follow in the footsteps his father never took. Given that premise, and the streak of bravado in his nature, it is not difficult to see how he came to steal Gard's little poem. (Ferris 1999: 36)

What the above passage clearly displays is the author's complete ignorance of classical poetics. Ferris is the modern-day Ariphrades who, according to Aristotle, 'failed to realize that it is precisely by being out of the ordinary that such expressions [which no one would use in conversation] elevate the style' (Aristotle 2013: 46). Poems do not simply convey. The 'affectations' rather are the poet's tools. Thickness, or compression, can be very, very good, as poetry too should strive for an emotive response and an artistic sense of inevitability. Of course, a biographer might be excused for such a response, but it is clearly the case that many an English critic suspected Thomas of being crafty, of playing childishly with words, simply because he himself was naughty (Moynihan 1966: 2-5). According to this rationale, every Welsh poet composing in cynghanedd, every writer who seeks to elevate the style, must be of dubious character! Aristotle's succinct response to such criticism seems sufficient to me. 'Some people find fault with this style and mock Homer for it, but they are wrong to do so' (2013: 46).

As mentioned, though the early poetry for many is the best, Dylan Thomas too came to feel that he needed to undo his sayings somewhat, to avoid the accusation of 'paradox or gibberish' (Aristotle 2013 edn: 46). As already suggested, this, I believe, is a familiar process to poets. '[M]oderation is needed' (Aristotle 2013 edn: 46). So Thomas modified his style as he externalised his gaze, but the 'affectations' remained central to his craft. William T. Moynihan went as far as to suggest that 'his obsession with craft is inherent in every line he wrote' (1966: 8), and John Goodby notes that 'examples of cynghanedd-style patterning can be found everywhere in his poems' (2013: 134), so it is little wonder that in a recent edition of Barddas, a poetry magazine dedicated to Cerdd Dafod, several prominent Welsh poets expressed their admiration of Dylan Thomas's 'complete dedication to the task of finding words' (Thomas, G. 2014: 40). They too recognise 'an ear for all music and a tongue against all humbug' 
(Thomas 1985 edn: 587). Though to the point and in the form of short essays, their genuine admiration for Dylan corresponds to 'the recent attempts to critically rehabilitate the 1940s and Thomas ... by critics who are also late modernist poets' (Goodby 2013: 454). This, perhaps, is not surprising, when we consider, for example, the final lines of 'Fern Hill', not only so obviously full of cynghanedd, but also of words so carefully selected, such as the inevitability of 'green and dying'.

Oh as I was young and easy in the mercy of his means,

Time held me green and dying

Though I sang in my chains like the sea

(Thomas 2000 edn: 135)

Did Dylan Thomas belong to the English? Does he now belong to the Welsh? Do we forget that his place in Poet's Corner was suggested by a former US President?

From the point of view of this paper's experiment, my time with Dylan suggests to me that in terms of the Welsh aesthetic described in the first chapter of Williams Pantycelyn, a Welsh poet, particularly a poet of cynghanedd - though poets of vers libre often write from words too, I hasten to add! - will find in this English poet's verse something undeniably comparable and familiar. More than any line of cynghanedd, this is Dylan's sense of poetry as object, a thing to be crafted and performed - the end result of his writing 'away from words'. This feature of his poetry, to me, as soon as this 'swap' was set in motion, was as easily recognisable as some of the Welsh characters of pura Walia in his Portrait 'stories about Welsh people' (1985 edn: 286). Reviewing the verse of Howard Harris in 1932, Dylan Thomas advised the poet that 'he must take care and time, weeding the hackneyed phrases from his verse, and concentrating upon it neither as a pastime nor a study, but as a work of art' (1932: 8). It is these very qualities, of course, which the Welsh poets of Barddas recognise and appreciate in Harris's reviewer too.

In terms of content, one could point out that some of his best poems, in which the me-you aesthetic is strongest, are located in Sir Gâr (Carmarthenshire), and that they address Welsh-speakers - his aunt in 'After the Funeral', his father in 'Do Not Go Gentle ...', and the boy-poet himself in 'Fern Hill'. The comparative appreciation of form, however, is not restricted to the poet's Welsh themes or landscapes.

This is not to say, however, that the sentence- 'He belongs to the English'-was not also true at the time, in 1938, nor that the internationalised 'Welsh poet' is a less hybrid and complex creature today. One thinks of Dylan Thomas's agents and publishers and editors, for example - the provincial poet's 'Dear Sir' in his letters (1985 edn: 19) — not forgetting his very English education in Wales, both at the grammar school and in his father's library (Thomas 1985 edn: 76-7). It is also worth considering his own scathing criticism too of those artists of Wales who 'anglicise 
themselves beyond recognition'. Setting the scene in London, and drawing perhaps on his own experiences there, his satire makes Saunders's 'He belongs to the English' look tame.

They ape the narrow ' $a$ '. They repudiate the Welsh language, whether they know it or not. By the condescending telling of comic apocryphal tales of Dai and Evan from the valleys, they earn, in the company of cultural lickspittles who condescend to them in turn, sorry dinners and rounds of flat drinks. They fall for the latest isms gullibly as pups for rubber bones. (1991d: 219)

Using English today, out of necessity, as it were, is not the same as 'Anglicization' (Jones, H.P. 1995: 163). This is Thomas's point of view. He had, according to John Davenport, 'a pride in being Welsh as violent as the most passionate nationalist' (1960: 76). Thomas, however, unlike many English-speaking Welshmen today, viewed English in Wales as a 'limitation', at least in the sense that an anglophone 'touches only upon poets who have written in English', whereas ' $[t]$ he most typical, if not the best, poetry turned out by a Welsh town should be written in Welsh; a local poet should write in the language of his locality' (Thomas 1971c edn: 97).

English too, for the Welsh artist, of course, is commercially advantageous, not limited to the readership and audiences in Wales. Languages are never antisocial, but rather hegemonic (Derrida 1996), and it seems only natural for a 'Welsh-English' poet to 'read anything in English' (Thomas 1985 edn: 730, 631), and to seek out the necessary audiences and media work which will sustain his or her work as a serious writer. This is partly why Dylan Thomas is continually seen by the undeniable expert on his verse, John Goodby, as a poet best served by the concept of 'British poetry' (Goodby 2013: 455; cf. Thomas 1985 edn: 729, 902), which, traditionally at least, has meant excluding the Welsh literary tradition and all contemporary poets who write in Welsh.

In 1938, with the depart poems of that year, it seems that Dylan Thomas was already moving in the direction to which Saunders Lewis alluded in his lecture on Anglo-Welsh literature, and in the above quotation concerning the anglophone writer's limitations in Wales, he comes very close to Saunders Lewis's point of view. After the elegy to his aunt, Ann - the scene, of course, is a Welsh funeral, with mourners singing hymns in Welsh - one cannot avoid noticing that Dylan Thomas's poems become more externalised and social, concerned with his day-to-day living in Laugharne. In the dialogue of the short stories, as in Under Milk Wood too, the ties with the English literary tradition are also loosened. Indeed, there is a line in one of Dylan Thomas's stories - 'Ooh, there's a pig of a night!' (1983 edn: 329)—that seems, at least to my knowledge, to be a translation of the Welsh, ' $\mathrm{Na}$ noson fochedd.' It could easily have been written by Saunders Lewis himself, in his own attempted AngloWelsh play, The Eve of Saint John (1996 edn: 15-31). For in trying to create a rich 
Anglo-Welsh dialect, comparable to that of the Anglo-Irish theatre, Lewis translated idioms and sayings from Welsh into English, but to no avail. Of that early attempt at Anglo-Welsh writing in 1920, Saunders Lewis later explained: 'I couldn't be satisfied with its diction and settled the issue by turning and learning to write in Welsh' (1955: 13). And that was that. But why?

The final part of this paper will try to answer this question.

\section{WELSH WRITING, IN WELSH}

Belonging to Wales, in Welsh, seems, at least to me, the most taken-for-granted thing. The national language defines its audience, irrespective of the work's theme or content, and indifferent to the author or reader's past. As for anglophone writing from Wales, the term 'Welsh writing in English' has replaced the questionable 'Anglo-Welsh' for some time. (Dylan Thomas in his letters uses 'Anglo-Welsh' (1985 edn: 336) but is more inclined to talk of 'Welsh people writing in English', or, more vaguely, of a 'poet connected with Wales', (1985 edn: 287, 385, 707, 741, 190, 199; cf. 1991b: 31-2; Ferris 1999: 159.) There is, of course, such a thing as English people writing in Welsh, and German writing in Welsh, and so on, even Welsh writing in Welsh. We call it all Welsh.

And today, as in the day of Taliesin or Dafydd ap Gwilym or even Saunders Lewis, the Welsh poet interacts with others, or else he or she stays at home and becomes a romantic, atticked away like Thomas Chatterton. As the language is but an occasional experience in our bilingual lives these days, we have to fight for it and plan for its future. (Welsh, 'the national tongue' (Thomas 1971c edn: 97), though unambiguous in its relationship to Wales, to Cymru, is nevertheless unstable, marginal and even alien to many who live in bilingual Cymru-Wales.) This is why, today, more so than ever, perhaps, we think vital and classical what the English call 'occasional' literature. It is how a poet hears his or her community and retains that sense of extroversion which changed Pantycelyn and Dylan Thomas's romantic verse into a me-you exchange.

After his failed Anglo-Welsh play, after Wallasey, after Wormwood Scrubs too, I think, perhaps, that it was from personal experience that Saunders cried, 'He belongs to the English.' Hybridity surely means that we are in part what we are seemingly not, and are in fact what we often profess not to be.

Saunders Lewis understood more than most of his contemporaries that Wales, in terms of politics and culture, increasingly belonged to England, ever since 1536 and the Acts of Union, and the Blue Books of 1847 (1962). What he sought was a return to Welsh life and to being able to offer the rest of the world a culture as grand as the Arthurian legends, the Mabinogi and the professional poetry of the Taliesin tradition. 
That is why he placed so much emphasis on the Welsh language and its social framework, using it too as the practical working language of his political party.

The change in Dylan Thomas's work after 1938, towards an external view of himself, towards a love of others, and of Wales, might suggest why Saunders Lewis, in 1953, decided to pay tribute to him, on hearing the sad news of his death. In a gracious and beautiful tribute - indeed, it reads as a blessing, and is regarded as a 'turning point' of sorts (Jones, H. P. 1995: 149; Thomas, M. W. 2000: 125) —he says, and I quote from the published translation, 'in his later years he became increasingly Welsh in his sympathies, and found themes in Welsh society'. He is 'the greatest Welsh poet writing in English in our time ... the most splendid English-speaking child Wales has produced for centuries'. He is particularly praised for avoiding 'convention', choosing rather to sing 'to the glory of the universe when it was the fashion for every prominent poet in Europe to sing despairingly and with passion and anguish of the end of civilisation' (1953: 9). Then again, in a book review in 1964, Saunders Lewis referred to the poet as 'a Christian religious poet of loveliness and power' - a poet perhaps comparable to Pantycelyn's mature verse, if not to the classical poets of Wales (1964b).

Thus far, the Welsh poet Gwilym Marles, Dylan Marlais Thomas's great-uncle, so vividly discussed by Professor M. Wynn Thomas in his book, In the Shadow of the Pulpit, has been the assured, tangible link between Dylan Thomas and Welsh poetry (2010; 2014b; Kershner 1976: 177). Gwilym Marles was a poet and Unitarian Minister in West Wales. Though the English-speaking great-nephew sang in a different language, residues of what he himself referred to as his 'hereditarily twisted imagination' (1985 edn: 137), one thinks, must still be there in his poetic DNA. Such romantic talk of 'Welsh imagination', however, seems unnecessary (Davies, W. 1986: 100). Literary traditions can be rediscovered, if not also reimagined, and it should be noted that it was none other than Saunders Lewis himself who secured Gwilym Marles's entry into the Oxford Book of Welsh Verse in the 1960s- his only serious claim to canonical status in Welsh literature. He suggested the name to the editor, Thomas Parry, and secured this tangible link between Dylan Thomas and the canon of Welsh poetry (Morgan 2013: 239). We can read into that fact what we may. (Was Lewis, yet again, reaching out to Dylan Thomas, as he secured this prestigious place for his great-uncle in that authoritative anthology?) My intention in this paper, however, was to suggest another way of linking Dylan Thomas to the Welsh bardic tradition, namely comparative poetics via Saunders Lewis's book on Williams Pantycelyn.

There remains one further way of making the connection, however, for though D. J. Thomas felt he had no choice but to raise his son in English, Dylan Thomas's readers today include those who enjoy a selection of his best stories and poems, along with his 'play for voices', in Welsh. (Indeed, if memory serves me well, I believe that I first read Dan y Wenallt [Under Milk Wood] in Welsh.) And a poem such as T. James 
Jones's translation of 'After the Funeral', and especially 'Fern Hill', feels returned in Welsh, as the language shift is reversed, and the shadow of the Blue Books removed.

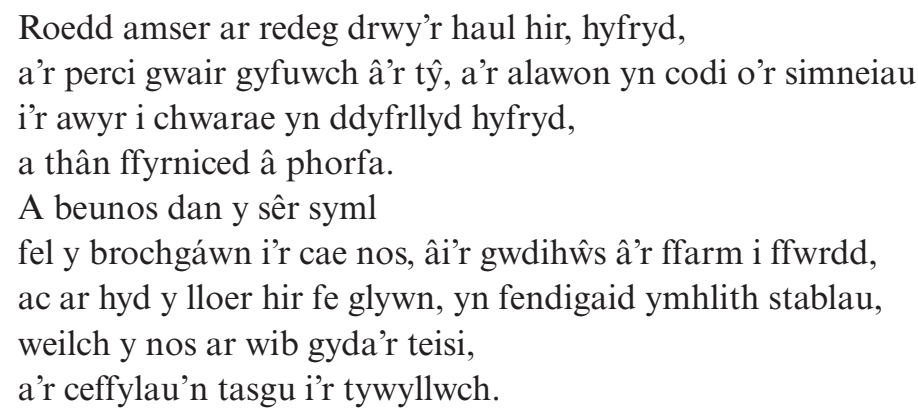

(Jones, T. J. 2008: 100)

This is Dylan, returned, reimagined, dehyphenated, in Welsh. In 1925, when Saunders Lewis set out the principles of Welsh nationalism, he realised that Wales barely existed as a nation in political terms. The following year, for example, when Mr Ellis Davies, Member of Parliament for Denbighshire, suggested in a debate in the House of Commons that a radio station should be established in North Wales, and that programmes frequently be broadcast in Welsh, the House's response was rapturous laughter: 'for he believes that is a difference between Wales and any other part of England; for he suggested that a distinctive language belongs to that part of England' (Lewis 1926).

D. J. Thomas, the English grammar school master, felt inclined to raise his son in Swansea and not Abertawe. His son just wanted to leave and find the real thing. He went east, to London, and then came back to Wales, and went further west. What would he and his father and mother have made of the bilingual Dylan Thomas exhibition at the National Library of Wales, in Aberystwyth, last year?

That centenary year too saw for the first time a study written in Welsh, by Kate Crockett, on Dylan Thomas's life and work (2014). It is a development wholly in keeping with Saunders Lewis's definition of the Anglo-Welsh in 1938. The Welsh in English, will, in time, be translated into Welsh, into the literary tradition of Taliesin (Lewis 1938: 12). And interestingly, though John Goodby argues that Dylan Thomas should be read in relation to a British canon, he too sees translation into Welsh as a matter 'of course' (2013: 450). At times, translation is a means of re-placing the text in the culture from which it came, as in Dylan Thomas's filmscript, 'Green Mountain, Black Mountain', produced both in English and in Welsh, in which the author delivered a 'many-faceted and comprehensive picture of Wales' (Ackerman 1995: 27):

Here in the chapels of Wales, Bethesda, Smyrna, Horeb, and Seion, the young and old come to sing and worship. To listen to the poetry and oratory of the preacher. ... 
[T] here are concerts and Eisteddfods, the young people dance, and the old, remembering, watch them. Here the bards and minstrels meet, as they met in the Middle Ages, though the lovely valleys of the south where they played on harps and sang are barnacled with smoking chimneys, and clustered with bad streets. (1995a edn: 30)

Critics often wonder why Dylan Thomas, on more than one occasion, defines a poem as that which is 'written for the love of Man and in praise of God' (Thomas, M. W. 2014: 41; Holbrook 1972: 63; Davies, A. T. 1964: 23; Hardy 2000: 16; Ferris 1999: 291; Goodby 2013: 251). From my 'swap' perspective, however, it reads as a line, if not taken and paraphrased from the medieval grammars of the Welsh poets, then at least in complete cynghanedd with them. On another occasion, 'Art is praise and it is sane to praise ...' said Thomas (1985 edn: 80). Dafydd ap Gwilym, the 14th-century master, would have said the same thing. To what extent was Dylan Thomas familiar with ap Gwilym's work, if at all? It is impossible to say. In his broadcast on 'Welsh Poetry', however, Thomas suggested that Henry Vaughan, 'who belonged to a very ancient Welsh family and who was educated in England, must surely have known ap Gwilym's poems. But he certainly did not follow in the exuberant bardmanship of that great court-poet, but derived, in the first place, his style and matter from George Herbert' (1991b edn: 32). In Dylan Thomas's case, it might be suggested that the exact opposite is true, and that this sentence at the very least suggests not only some knowledge of 'ap Gwilym's poems', but admiration too. And as for the praise of 'God' and 'man', the Welsh medieval grammars, edited and published by the University of Wales press in 1934, stated clearly that man was to praise two things: 'peth ysprydawl a pheth corfforawl ... megys Duw ... megys dyn'. 'Two things should be praised—namely the spiritual and the material; a spiritual thing such as God and the saints; a material thing, such as man, or animal, or place' (Williams, G. J. \& Jones, E. J. 1934: 15; my translation).

Had the learned D. J. Thomas read Dafydd ap Gwilym to his boy, instead of Shakespeare - our assumption, of course, is that he did not-or more importantly, had he, Dylan Thomas, been educated in a Welsh school, his story, and Wales's story, might have been a very different one. That is what Saunders Lewis saw at the beginning of the 20th century, and what he sought to change. He rediscovered the Welsh bardic tradition, and made it something vital to Welsh life. Without it, it was hardly surprising that young poets in Wales sought to imitate Eliot or Auden or Day Lewis, rather than develop their craft from the great masters of the Welsh literary tradition (1945 edn). Lewis too loved Shakespeare, especially Hamlet, but he read him comparatively, as he did Sophocles, Dante and the neoclassical playwrights of France; for he knew that the Mabinogi, the Arthurian legend, and the Welsh bardic tradition, from the 6th century to the present day, made Welsh one of the richest literary traditions in Europe. 
Comparative poetics offers a way of understanding what we have in common, what indeed is universal, but, also, what is different. Dylan Thomas's hybridity, rightly hailed as 'the source of his poetic originality and power', and perhaps a reason for his popularity in America too (Goodby 2013: 21, 279-91, 439; Gramich 2004: 250; Davies, J. A. 2001: 164), was dependent on there being a Welsh life, a Welsh language, a Welsh culture: a Welsh-speaking mother and father, a Welsh-speaking aunt, a Welsh-speaking farm and chapel in 'colourful Carmarthenshire' (Thomas 1985 edn: 561):

The sound of the colliers' voices at night left on the air above the crippled street. 'Nos da Will.' 'Nos da, Shoni.' 'Nos da, Evan.' 'Nos da.' 'Nos da.' (1991c edn: 204)

Ensuring that there exist in Wales villages, towns and entire counties and regions where the Welsh language is by far the predominant tongue is good not only for Welsh literature, but also for Welsh writing in English, and all who would visit Cymru-Wales.

The Welsh language offers its nationhood to all. It is what makes the bilingual, two-tongued and crackling sea of Dylan Thomas's Swansea-Abertawe and of Talacharn-Laugharne, so appealing, and so full of life and potential. It is why so many non-Welsh speaking parents in Cymru-Wales choose to send their children to Welsh-medium schools. It is why so many English-language authors choose to learn Welsh, 'swayed' by Welsh language culture, as John Goodby suggests (2013: 441) and that choice of verb, of course, reinforces its sea-like relationship with the dominating lands of English.

Language is how we mean. It is how we connect with each other, and with all who made us. It is why the humanists, throughout Europe, in the renaissance period, placed language at the heart of their studia humanitatis. It is language that makes us human; that makes us humane. Poets with such a high regard for words, and who make of them narratives, images, plays and dreams, are inevitably the ones who touch us most deeply. Dylan Thomas was such a poet.

As already mentioned, he is no longer an English monoglot poet in Wales, and, strangely enough, by means of the British Academy's literary exchange, it is he, Dylan, 'a language changer' (Hardy 2000: 51), who best explains to me now why the recent endeavours by the Welsh government to revitalise the Welsh language are proving so ineffective. 'Work from words ... not towards words' (Thomas 1985 edn: 182). Eureka! Having a government policy and a government strategy for the Welsh language, i.e. targets, objectives, visions - which, of course, are well intentioned and good - while government ministers and departments, local councils and institutions work almost completely through the medium of English — towards Welsh, and not from it - is simply ineffective and counterproductive. Florence Hannah and D. J. Thomas raised their son in English, for they saw that the government and the universities of the day 
did not use the Welsh language in any creative sense, and neither wanted their child to live 'under the hatches'.

'Work from words, not towards words'. This is why we remember Dylan Thomas as a gifted and serious poet, who gave the English-reading and listening world several powerful and perfectly crafted poems. Dylan's word for this effect was 'inevitable' - 'The music is made, the magic is done, the sound and the spell remain' (1985 edn: 578, 591) _ and in terms of such inevitable lines and poems, he produced more than most poets achieve in a long lifetime (cf. Dylan Thomas edn 1985: 14). He studied hard, and he loved words dearly. 'Astudio geiriau a'u caru.'

In his beautiful tribute to Dylan Thomas in 1953, Saunders Lewis mentions that the two of them met only the once, and had a pleasant conversation. I am grateful to the British Academy for letting me bring them together once again by means of this lecture series, and hope very much that this socio-literary experiment will be of use to others.

\section{REFERENCES}

Ackerman, J. (ed.) (1995), Dylan Thomas: The Filmscripts (London, J. M. Dent).

Ackerman, J. (1998), Welsh Dylan: Dylan Thomas's Life, Writing, and his Wales (Bridgend, Seren).

ap Gwilym, D. (1952 edn), 'Yr Wylan', in Gwaith Dafydd ap Gwilym, ed. T. Parry (Caerdydd, Gwasg Prifysgol Cymru), 313.

ap Gwilym, D. (2007 edn), 'Edifeirwch', ed. A. C. Lake (Abertawe, Prifysgol Abertawe), n. 119, http:// www.dafyddapgwilym.net/cym/3win.htm

Aristotle (2013 edn), Poetics: A New Translation by Anthony Kenny (Oxford, Oxford University Press).

Audley, F. (2014), 'Michael D. Higgins Wales Visit Starts by Honouring Dylan Thomas', The Irish Post (28 October),

http://www.irishpost.co.uk/news/michael-d-higgins-wales-visit-starts-honouring-dylan-thomas

Bateson, F. W. (1972), “'The Conversation of Prayer”: An Anglo-Welsh Poem', in W. Davies (ed.), Dylan Thomas: New Critical Essays (London, J. M. Dent), 221-7.

Bhabha, H. K. (1994), The Location of Culture (London, Routledge).

Bloom, H. (1973), The Anxiety of Influence (Oxford, Oxford University Press).

Brinnin, J. M. (1957), Dylan Thomas in America (New York, Viking Books).

Chapman, T. R. (2006), Un Bywyd o Blith Nifer: Cofiant Saunders Lewis (Llandysul, Gwasg Gomer).

Crehan, S. (2001), 'The Lips of Time", in J. Goodby \& C. Wigginton (eds), Dylan Thomas: Contemporary Critical Essays (Basingstoke, Hants, Palgrave Macmillan), 46-64.

Crockett, K. (2014), Mwy na Bardd: Bywyd a Gwaith Dylan Thomas (Cyhoeddiadau Barddas).

Daiches, D. (1966 edn), 'The Poetry of Dylan Thomas', in C. B. Cox (ed.), Dylan Thomas: A Collection of Critical Essays (Englewood Cliffs, NJ, Prentice-Hall), 14-24.

Davenport, J. (1960), 'John Davenport', in E. W. Tedlock (ed.) Dylan Thomas: The Legend and the Poet, (London, Heinmann), 74-81.

Davies, A. T. (1962), 'William Barnes, Gerard Manley Hopkins, Dylan Thomas: the Influence of Welsh Prosody on Modern English Poetry', in Proceedings of the Third Congress of the International Comparative Literature Association (The Hague, Mouton), 90-122. 
Davies, A. T. (1964), Dylan: Druid of the Broken Body (London, J. M. Dent).

Davies, J. A. (2001), 'Questions of Identity: The Movement and "Fern Hill”', in J. Goodby \& C. Wigginton (eds), Dylan Thomas: Contemporary Critical Essays (Basingstoke, Hants, Palgrave Macmillan), $158-71$.

Davies, P. (1973), 'Aspects of his Work: His Criticism', in A. R. Jones \& G. Thomas (eds), Presenting Saunders Lewis (Cardiff, University of Wales Press), 93-105.

Davies, W. (1986), Dylan Thomas: Open Guides to Literature (Milton Keynes, Open University Press).

Derrida, J. (1996), 'Jacques Derrida: Talking Liberties', videotaped interview for Oxford Amnesty Lectures, Films for the Humanities (Oxford).

Edwards, H. M. (2007), 'The Literary Context', dafyddapgwilym.net, http://www.dafyddapgwilym.net/docs/the \%20literary\%20context.pdf

Eliot, T. S. (1995 edn), 'Tradition and the Individual Talent', in D. Lodge (ed.), 20th Century Literary Criticism (London, Longman), 71-7.

Ellis, H. (ed.) (2014), Dylan Thomas: A Centenary Celebration (London, Bloomsbury).

Elton, O. (1907), Modern Studies (London, Edward Arnold).

Ferguson, M., Slater, M. J. \& Stallworthy, J. (eds) (2005), The Norton Anthology of Poetry: Fifth Edition (New York, W. W. Norton)

Ferris, P. (1999), Dylan Thomas: The Biography: New Edition (London, J. M. Dent).

Fryer, J. (1993), Dylan: The Nine Lives of Dylan Thomas (London, Kyle Cathie).

Goodby, J. (2013), The Poetry of Dylan Thomas: Under the Spelling Wall (Liverpool, Liverpool University Press), http://dx.doi.org/10.5949/liverpool/9781846318764.001.0001

Goodby, J. \& Wigginton, C. (2001), 'Introduction', in J. Goodby \& C. Wigginton (eds), Dylan Thomas: Contemporary Critical Essays (Basingstoke, Hants, Palgrave Macmillan), 1-19.

Gramich, K. (2004), “Extravagant and Wheeling Stranger[s]”: Dylan Thomas, Derek Walcott and the House of English Literature', in A. von Rithkirch \& D. Williams (eds), Beyond the Difference:

Welsh Literature in Comparative Contexts (Cardiff, University of Wales Press), 237-51.

Hallam, T. (2012), 'r/hanfodoli', in T. Hallam \& A. Price (eds), Ysgrifau Beirniadol XXXI (Bethel, Gwasg Gee), 49-91.

Hardy, B. (2000), Dylan Thomas: An Original Language (London, The University of Georgia Press).

Heidegger, M. (1993 edn), Being and Time, trans. J. Macquarrie \& E. Robinson (Oxford, Blackwell).

Holbrook, D. (1972), Dylan Thomas: The Code of Night (London, The Athlone Press).

Hopwood, M. (2014), 'Oedd Dylan Thomas yn cynganeddu?' (BBC Cymru/Wales), http://www.bbc.co.uk/guides/zybyyrd

Husserl, E. (1970), The Crisis of European Sciences and Transcendental Phenomenology, trans. D. Carr (Evanston, IL, Northwestern University Press).

Jones, G. (1954), 'Dylan Thomas and Welsh', Dock Leaves (Spring), 24-5.

Jones, H. P. (1995), 'Saunders Lewis a'r Eingl-Gymry', in M. W. Thomas (ed.), DiFfinio Dwy Lenyddiaeth Cymru (Caerdydd, Gwasg Prifysgol Cymru), 145-69.

Jones, T. J. (2008), Nawr (Cyhoeddiadau Barddas).

Jones, T. J. (2014), 'Various Versions', in H. Ellis (ed.), Dylan Thomas: A Centenary Celebration (London, Bloomsbury), 228-37.

Kershner Jr., R. B. (1976), Dylan Thomas: The Poet and his Critics (Chicago, IL, American Library Association).

Kierkegaard, S. (1965 edn), The Journals of Kierkegaard ed. and trans. A. Dru (London, Fontana Books). Lewis, S. (1926), 'Nodiadau'r Mis', Y Ddraig Goch, 1:7 (Rhagfyr [December] 1926), 1.

Lewis, S. (1927), Williams Pantycelyn (Llundain, Foyle's Welsh Depôt).

Lewis, S. (1929), 'The Literary Man's Life in Wales', Welsh Outlook (16 October), 294.

Lewis, S. (1930a), Monica (Aberystwyth, Gwasg Aberystwyth).

Lewis, S. (1930b), 'The Banned Wireless Talk on Welsh Nationalism' (Caernarvon, Swyddfa'r Blaid Genedlaethol). 
Lewis, S. (1932), Braslun o Hanes Llenyddiaeth Gymraeg: Y Gyfrol Gyntaf Hyd at 1535 (Caerdydd, Gwasg Prifysgol Cymru).

Lewis, S. (1938), Is There an Anglo-Welsh Literature? (Cardiff, Guild of Graduates of the University of Wales).

Lewis, S. (1945 edn), 'Diwylliant yng Nghymru', Ysgrifau Dydd Mercher (Cyhoeddiadau'r Clwb Llyfrau Cymraeg), 100-6.

Lewis, S. (1953), 'Dylan Thomas', Dock Leaves (Spring), (Pembroke Dock, Dock Leaves Press), 8-9.

Lewis, S. (1955), 'By Way of an Apology', Dock Leaves (Winter), (Pembroke Dock, Dock Leaves Press), 10-3.

Lewis, S. (1962), Tynged yr Iaith (BBC Cymru), https://www.llgc.org.uk/ymgyrchu/Iaith/TyngedIaith/tynged.htm; The Fate of the Language, trans. G. A. Williams, http://quixoticquisling.com/testun/saunders-lewis-fate-of-the-language.html

Lewis, S. (1964a), 'A Member of Our Older Breed', The Western Mail: Literary Review (4 December), 4.

Lewis, S. (1964b), 'Dylan Thomas's Private Life', The Western Mail (9 July), 6.

Lewis, S. (1965), 'Welsh Literature and Nationalism', The Western Mail (13 March), 9.

Lewis, S. (1973a edn), 'The Caernarfon Court Speech', in A. R. Jones \& G. Thomas (eds), Presenting Saunders Lewis (Cardiff, University of Wales Press), 115-26.

Lewis, S. (1973b edn), 'The Essence of Welsh Literature', in A. R. Jones \& G. Thomas (eds), Presenting Saunders Lewis (Cardiff, University of Wales Press), 154-8.

Lewis, S. (1973c edn), 'Dafydd ap Gwilym', Blackfriars (March), in A. R. Jones \& G. Thomas (eds) Presenting Saunders Lewis (Cardiff, University of Wales Press) 159-63.

Lewis, S. (1985 edn), 'Un Iaith i Gymru', in Canlyn Arthur: Ysgrifau Gwleidyddol Saunders Lewis (Llandysul, Gwasg Gomer), 61-5.

Lewis, S. (1993 edn), Letters to Maragret Gilcriest, ed. M. S. Jones, N. Thomas \& H. P. Jones (Cardiff, University of Wales Press).

Lewis, S. (1996 edn), 'The Eve of Saint John', in Dramâu Saunders Lewis: y Casgliad Cyflawn Cyfrol I, ed. I. M. Williams (Caerdydd, Gwasg Prifysgol Cymru), 15-31.

Lewis, S. (2000a edn), 'Cymru Fydd', in Dramâu Saunders Lewis: y Casgliad Cyflawn Cyfrol II, ed. I. M. Williams (Caerdydd, Gwasg Prifysgol Cymru), 565-634.

Lewis, S. (2000b edn), 'Merch Gwern Hywel', in Dramâu Saunders Lewis: y Casgliad Cyflawn Cyfrol II, ed. I. M. Williams (Caerdydd, Gwasg Prifysgol Cymru), 657-704.

Llwyd, A. (1978), 'Cynghanedd and English Poetry’ Poetry Wales, 14: 1 (Summer), 23-58.

Lucas, R. (1981), The Voice of a Nation? A Concise Account of the BBC in Wales: 1923-1973 (Llandysul, Gwasg Gomer).

Mathias, R. (1954), 'A Merry Manshape', Dock Leaves (Spring), 30-9.

Maud, R. (2003), Where Have the Old Words Got Me?: Explications of Dylan Thomas's Collected Poems (Cardiff, University of Wales Press).

Morgan, D. Ll. (2013), Y Brenhinbren: Bywyd a Gwaith Thomas Parry 1904-1985 (Llandysul, Gwasg Gomer).

Moynihan, W. T. (1966), The Craft and Art of Dylan Thomas (New York, Cornell University Press).

Olson, E. (1966 edn), 'The Universe of the Early Poems', in C. B. Cox (ed.), Dylan Thomas: A Collection of Critical Essays (Englewood Cliffs, NJ, Prentice-Hall), 45-59.

Parry, T. (ed.) (1952) Gwaith Dafydd ap Gwilym (Caerdydd, Gwasg Prifysgol Cymru).

Price, C. (1953), [part of] 'Seventeen Further Memoirs', in M. Grindea (ed.), Adam: International Review, 238: 37-9.

Reid, A. (1960), 'Alastair Reid', Dylan Thomas: The Legend and the Poet, ed. E. W. Tedlock (London, Heinmann), 53-4.

Roberts, G. T. (2011), The Language of the Blue Books: Wales and Colonial Prejudice (Cardiff, University of Wales Press). 
Ryan, N. (2014), 'Ó Cuirreáin Has Formally Stepped Down As Irish Language Commissioner', TheJournal.ie (23 February),

http://www.thejournal.ie/irish-language-commission-formally-steps-down-1330219-Feb2014

Sartre, J-P. (1958 edn), Being and Nothingness: An Essay on Phenomenological Ontology, trans. H. E. Barnes (London, Methuen).

Sinclair, A. (1999). Dylan the Bard: A Life of Dylan Thomas (London, Constable).

Smith, S. (2001), “"The little arisen original monster”: Dylan Thomas's Sour Grapes', in J. Goodby \& C. Wigginton (eds), Dylan Thomas: Contemporary Critical Essays (Basingstoke, Hants, Palgrave Macmillan), 20-45.

Stanford, D. (1954), Dylan Thomas (London, Neville Spearman).

Thomas, D. (1932), 'A Modern Poet of Gower: Anglo-Welsh Bards', Herald of Wales (25 June), 8.

Thomas, D. (1953), 'Address to the Scottish Society of Writers in Edinburgh', quoted in M. Grindea (ed.), Adam: International Review, 238: 68.

Thomas, D. (1971a edn), 'Poetic Manifesto', in Dylan Thomas: Early Prose Writings, ed. W. Davies (London, J. M. Dent), 154-60.

Thomas, D. (1971b edn), review of The Solitary Way by William Soutar, Squared Circle by William Montgomerie, and Thirty Pieces by Sydney Salt, in Dylan Thomas: Early Prose Writings, ed. W. Davies (London, J. M. Dent), 165-7.

Thomas, D. (1971c edn), 'The Poets of Swansea', in Dylan Thomas: Early Prose Writings, ed. W. Davies (London, J. M. Dent), 97-121.

Thomas, D. (1983 edn), Dylan Thomas: The Collected Stories, ed. L. Norris (London, J. M. Dent).

Thomas, D. (1985 edn), Dylan Thomas: The Collected Letters, ed. P. Ferris (New York, Macmillan).

Thomas, D. (1991a edn), 'Reminiscences of Childhood', in Dylan Thomas: The Broadcasts, ed. R. Maud (London, J. M. Dent), 3-8.

Thomas, D. (1991b edn), 'Welsh Poetry', in Dylan Thomas: The Broadcasts, ed. R. Maud (London, J. M. Dent), 31-49.

Thomas, D. (1991c edn), 'Living in Wales', in Dylan Thomas: The Broadcasts, ed. R. Maud (London, J. M. Dent), 202-6.

Thomas D. (1991d edn), 'Swansea and the Arts', in Dylan Thomas: The Broadcasts, ed. R. Maud (London, J. M. Dent), 218-22.

Thomas D. (1991e edn), Dylan Thomas: The Poems Edited and Introduced by Daniel Jones (London, J. M. Dent)

Thomas D. (1995a edn), 'Wales—Green Mountain, Black Mountain', in Dylan Thomas: The Filmscripts, ed. J. Ackerman (London, J. M. Dent), 26-31.

Thomas D. (1995b edn), 'The Three Weird Sisters', in Dylan Thomas: The Filmscripts, ed. J. Ackerman (London, J. M. Dent), 281-319.

Thomas, D. (2000 edn), Dylan Thomas: Collected Poems 1934-1953, ed. W. Davies \& R. Maud (London, Phoenix).

Thomas, G. (2014), 'Barn Tri am D. T.', Barddas, 324 (Hydref [October] 2014), 40-1.

Thomas, M. W. (1999), Corresponding Cultures: The Two Literatures of Wales (Cardiff, University of Wales Press).

Thomas, M. W. (2000), “He belongs to the English”: Welsh Dylan and Welsh-language Culture', in J. Goodby \& C. Wigginton (eds), The Swansea Review, 20: Under the Spelling Wall (Swansea, University of Wales Swansea), 122-34.

Thomas, M. W. (2010), “Marlais": Dylan Thomas and the "Tin Bethels", in M. W. Thomas, In the Shadow of the Pulpit: Literature and Nonconformist Wales (Cardiff, University of Wales Press), 227-55.

Thomas, M. W. (2014a), [comments as Chair made at the end of the lecture delivered to the British Academy in London], (24 October), http://www.britac.ac.uk/events/2014/Curse_bless_me_now.cfm 
Thomas, M. W. (2014b), 'Marlais', in H. Ellis (ed.), Dylan Thomas: A Centenary Celebration (London, Bloomsbury), 30-41.

Tindall, W. Y. (1996), A Reader's Guide to Dylan Thomas (Syracuse, NY, Syracuse University Press).

Vendler, H. (2003), Coming of Age as a Poet: Milton, Keats, Eliot, Plath (Cambridge MA, Harvard University Press).

Wain, J. (1965), 'Dylan Thomas Today', The New York Review of Books, IV (25 February), 14.

Wain, J. (1966 edn), 'Dylan Thomas: A Review of His Collected Poems', in C. B. Cox (ed.), Dylan Thomas: A Collection of Critical Essays (Englewood Cliffs, NJ, Prentice-Hall), 9-13.

Wain, J. (ed.) (2003 edn), The Oxford Anthology of English Poetry: Volume II: Blake to Heaney (Oxford, Oxford University Press).

Walters, D. G. (2002), Canciones and the Early Poetry of Lorca: A Study in Critical Methodology and Poetic Maturity (Cardiff, University of Wales Press).

Wigginton, C. (2001), "Birth and Copulation and Death": Gothic Modernism and Surrealism in the Poetry of Dylan Thomas', in J. Goodby \& C. Wigginton (eds), Dylan Thomas: Contemporary Critical Essays (Basingstoke, Hants, Palgrave Macmillan), 85-105.

Williams, D. G. (2012), Black Skins, Blue Books: African Americans and Wales (Cardiff, University of Wales Press).

Williams, G. A. (1984), personal letter to Saunders Lewis's daughter, Mair Saunders Jones (21 July), in collection NLW MS23226D, Saunders Lewis Manuscripts: Lewis Family Letters (National Library of Wales).

Williams, G. J. \& Jones, E. J. (eds) (1934), Gramadegau'r Penceirddiaid (Caerdydd, Gwasg Prifysgol Cymru).

Williams, W. (1855 edn), 'Guide me, O Thou Great Jehovah!', in The New Congregational Hymn Book (London, Jackson Walford \& Hodder for the Congregational Union of England \& Wales), no. 660 .

Williams, W. (1964 edn), 'Theomemphus', in Gweithiau William Williams Pantycelyn: Cyfrol I, ed. G. M. Roberts (Caerdydd, Gwasg Prifysgol Cymru), 193-399.

Williams, W. (1967 edn), 'Ductor Nuptiarum neu Gyfarwyddwr Priodas', in Gweithiau William Williams Pantycelyn: Cyfrol II, ed. G. H. Hughes (Caerdydd, Gwasg Prifysgol Cymru), 243-303.

Note on the author: Professor Tudur Hallam is Professor and Chair of Welsh at Swansea University. His research interests include comparative poetics, theatre and the Welsh literary tradition. Related publications include a monograph on Saunders Lewis's theatre Saunders y Dramodydd (Gwasg y Bwthyn, 2013), the introduction and a collection of poems in Beirdd Bro Eisteddfod Sir Gâr (2014), and an article in English on translating the poetry of Menna Elfyn in Slanderous Tongues (2010). He was awarded the Chair for his strict-metre poem 'Ennill Tir' at the National Eisteddfod of Wales in 2010.

t.r.hallam@abertawe.ac.uk

To cite the article: Tudur Hallam (2015), "CCurse, bless, me now": Dylan Thomas and Saunders Lewis', Journal of the British Academy, 3: 211-253.

DOI $10.85871 / \mathrm{jba} / 003.211$ 
This article is licensed under a

Creative Commons Attribution-NonCommercial-NoDerivs 3.0 Unported License.

Journal of the British Academy (ISSN 2052-7217) is published by

The British Academy - the national academy for the humanities and social sciences.

10-11 Carlton House Terrace, London, SW1Y 5AH

www.britishacademy.ac.uk 